\title{
Range and niche expansion through multiple interspecific hybridization - a Genotyping by Sequencing analysis of Cherleria (Caryophyllaceae)
}

Abigail Jane Moore ( $\square$ abigail.j.moore@ou.edu )

University of Oklahoma https://orcid.org/0000-0002-0712-3842

Jennifer A. Messick

University of Central Oklahoma

Joachim W. Kadereit

Johannes Gutenberg Universitat Mainz

Research article

Keywords: Phylogenomic, RADseq, Minuartia, Alps, European High Mountains, edaphic evolution, calcicole, calcifuge, serpentine

Posted Date: May 19th, 2020

DOI: https://doi.org/10.21203/rs.3.rs-22788/v1

License: (c) (i) This work is licensed under a Creative Commons Attribution 4.0 International License. Read Full License

Version of Record: A version of this preprint was published on March 10th, 2021. See the published version at https://doi.org/10.1186/s12862-020-01721-5. 


\section{Abstract \\ Background}

Cherleria (Caryophyllaceae) is a circumboreal genus that also occurs in the high mountains of the northern hemisphere. In this study, we focus on a clade that diversified in the European High Mountains, which was identified using nuclear ribosomal (nrDNA) sequence data in a previous study. With the nrDNA data, all but one species was monophyletic, with little sequence variation within most species. Here, we use genotyping by sequencing (GBS) data to determine whether the nrDNA data showed the full picture of the evolution in the genomes of these species.

\section{Results}

The overall relationships found with the GBS data were congruent with those from the nrDNA study. Most of the species were still monophyletic and many of the same subclades were recovered, including a clade of three narrow endemic species from Greece and a clade of largely calcifuge species. The GBS data provided additional resolution within the two species with the best sampling, $C$. langii and $C$. laricifolia, with structure that was congruent with geography. In addition, the GBS data showed significant hybridization between several species, including species whose ranges did not currently overlap.

\section{Conclusions}

The hybridization led us to hypothesize that lineages came in contact on the Balkan Peninsula after they diverged, even when those lineages are no longer present on the Balkan Peninsula. Hybridization may also have helped lineages expand their niches to colonize new substrates and different areas. Not only do genome-wide data provide increased phylogenetic resolution of difficult nodes, they also give evidence for a more complex evolutionary history than what can be depicted by a simple, branching phylogeny.

\section{Introduction}

The importance of hybridization in the generation of biological diversity is becoming increasingly clear (Arnold 1997, Abbott et al. 2013, Grant and Grant 2019). Hybrid swarms or hybrid species, homoploid or polyploid, are the best-studied examples of hybridization (Arnold 1997, Rieseberg et al. 2003, Gross et al. 2007). However, introgression, the presence of a much smaller fraction of the genome of one species in another species, is also of great evolutionary significance (Anderson 1949, Heiser 1973, Rieseberg \& Wendel 1993, Arnold 2016). The generation of massive amounts of DNA sequence data through next generation sequencing has led to the recognition of introgression on a scale that was not previously suspected (e.g., Edelman et al. 2019, Giska et al. 2019). 
While contemporary interspecific hybridization is relatively common in plants (Mallet 2005; Whitney et al. 2010), past hybridization sometimes took place when patterns of geographical distribution often were very different from those today. Species distribution ranges have been highly dynamic in response to past changes of climate. These patterns have been documented in detail, particularly for the most recent geological past, using various sources of evidence (e.g., Soltis et al. 1997, Comes and Kadereit 1998, Soltis et al. 2006, Holderegger and Thiel-Egenter 2009, Sklenář et al. 2014, Antonelli et al. 2018). Climateinduced range shifts and climate-induced disturbance of the environment would have promoted the origin of hybrids between previously geographically or ecologically isolated taxa as well as their establishment in previously uninhabited areas (Manton 1950, Stebbins 1950, Anderson \& Stebbins 1954, Arnold 2016).

The European Alps are a model system for examining how a mountain biota has responded to climate change (Comes and Kadereit 1998, Hewitt 2004, Schönswetter et al. 2005, Theil-Egenter et al. 2011). The Alps were extensively glaciated during the Last Glacial Maximum (LGM) and previous glacial periods. The organisms living in the Alps survived these glaciations in refugia (e.g., Schönswetter et al. 2005, Alvarez et al. 2009, Médail and Diadema 2009, Schneeweiss and Schönswetter 2011, Westergaard et al. 2011), often implying substantial shifts of geographical range into lowland areas.

It has long been recognized that the flora of the Alps is intimately linked to that of neighboring mountain ranges, especially the Pyrenees, Apennines, Carpathians, Dinarids, and Balkans (Christ 1867, Engler 1879, Aeschimann et al. 2004, Ronikier 2011, Kadereit 2017). Due to their linkage, these mountain ranges together are considered the European Alpine System (EAS; Ozenda, 1985, 2009). Although, glaciation was only local in many of the mountain ranges outside the Alps, substantial shifts in the elevation of the various habitat zones in response to Quaternary climatic oscillations occurred in all ranges. Thus, species would have been exchanged between mountain ranges during glacial periods, but not during interglacial periods.

On the background of the dynamic range history of plant taxa in the EAS we here examine the role of hybridization in the evolution of a subclade of Cherleria L. (formerly Minuartia L., Caryophyllaceae; Dillenberger and Kadereit 2014, Moore and Dillenberger 2017) endemic to the EAS. Cherleria as a whole contains 19 species and has a circumboreal distribution, with incursions into the high mountains of Eurasia and North America. It is most diverse in the EAS, with a clade of 11 species centered in the Alps and the Balkan Peninsula (Clade $\mathrm{C}$ of Moore and Kadereit 2013 based on nuclear ribosomal DNA, nrDNA, sequence data, Fig. 1). An analysis of biogeography and evolution of substrate preference showed that the group appeared to have initially diversified on the Balkan Peninsula, with multiple separate colonizations of the northern and western mountain ranges of the EAS (Moore and Kadereit 2013). More detailed work on two species of the group provided evidence for hybridization. A study of $C$. sedoides $L$. (Valtueña et al. 2015, Moore et al. 2017) showed high chloroplast DNA (cpDNA) haplotype and nrDNA ribotype diversity throughout its wide range (including the Alps, the Balkan Peninsula, the Pyrenees, and Scotland). It also showed that the most common cpDNA haplotype clade most likely originated through hybridization of $C$. sedoides with an extinct species of the genus (Moore et al. 2017). A study of $C$. laricifolia (L.) lamonico using AFLPs and chloroplast haplotypes also showed high diversity throughout 
its range, and hypothesized gene flow between serpentine and non-serpentine populations during the origin of the serpentine endemic ssp. ophiolitica (Pignatti) lamonico (Moore et al. 2013).

In this study, we re-examine the EAS clade of Cherleria in both a phylogenetic and a phylogeographic context using genotyping by sequencing (GBS) data. In particular, we want: 1) To examine interspecific relationships to determine whether the nrDNA data as used by Moore and Kadereit (2013) are representative of the rest of the genome or represent an outlying clean signal. 2) To assess the role of hybridization in the evolution of the group. 3) To examine whether evidence of hybridization provides information about the past distribution of species, which could not have been inferred by other evidence.

\section{Results}

\section{Sequencing:}

Of the plants we sequenced, 273 of the 290 were sequenced successfully. These plants had between 100,095 and $8,967,450$ reads (mean \pm standard deviation of $1,588,247 \pm 1,281,318$ ), of which 32,862 to 622,739 were unique $(191,523 \pm 125,227$; Additional file 1$)$. It is possible that some of these repeated reads were due to PCR duplicates, but as the sequenced fragments each start and end at a restriction site, instead of being randomly sheared, we did not have a way to distinguish PCR duplicates from independent sequences from the same locus. In the final analysis, 267 different loci were used in the Individual dataset (consisting of all sampled individuals), 352 were in the Population dataset (consisting of the single best individual from each population), and 380 were in the Taxon dataset (consisting of one composite individual from the single population per taxon, Table 1), when all species were analyzed together. When $C$. laricifolia was analyzed by itself (only at the Individual level), 465 loci were used, and when $C$. langii (G. Reuss) A.J. Moore \& Dillenb. was analyzed by itself (also only at the Individual level), 404 loci were used. 
Table 1

Voucher and locality information.

\begin{tabular}{|c|c|c|c|c|c|}
\hline species & code & locality & collection & $\mathbf{N}$ & $\mathbf{T}$ \\
\hline baldaccii & BA231 & Albania, Tropojë & Moore et al. 1522 & 5 & \\
\hline baldaccii & BA232 & Albania, Tropojë & Moore et al. 1523 & 5 & * \\
\hline capillacea & CA217 & $\begin{array}{l}\text { France, Languedoc-Roussillon, } \\
\text { Hérault }\end{array}$ & Moore \& Klein 1437 & 5 & * \\
\hline capillacea & CA233 & Albania, Tropojë & Moore \& Welch 1524 & 5 & * \\
\hline capillacea & CA48 & France, Rhône-Alpes, Isère & Moore et al. 1193 & 5 & \\
\hline capillacea & CA53 & $\begin{array}{l}\text { Italy, Friuli-Venezia, Giulia, } \\
\text { Pordenone }\end{array}$ & Moore 1044 & 0 & \\
\hline capillacea & CA64 & $\begin{array}{l}\text { France, Provence-Alpes-Côte d'Azur, } \\
\text { Alpes de Haute Provence }\end{array}$ & Moore et al. 1241 & 5 & \\
\hline dirphya & DI230 & Greece, Sterea Ellada, Evvia & Moore et al. 1513 & 5 & * \\
\hline doerfleri & D0222 & $\begin{array}{l}\text { Greece, Anatoliki Makedonia kai } \\
\text { Thraki: Drama }\end{array}$ & Moore 1482 & 2 & * \\
\hline garckeana & GA223 & Greece, Kentriki Makedonia, Kilkis & Moore 1493 & 5 & \\
\hline garckeana & GA224 & Greece, Kentriki Makedonia, Pella & Moore 1500 & 4 & \\
\hline garckeana & GA226 & Greece, Dytiki Makedonia, Grevena & Moore 1507 & 5 & \\
\hline garckeana & GA227 & Greece, Epeiros, loannina & Moore 1508 & 5 & \\
\hline garckeana & GA228 & Greece, Epeiros, loannina & Moore 1510 & 5 & * \\
\hline langii & LN38 & $\begin{array}{l}\text { Slovakia, Žilina, Krivánska Malá } \\
\text { Fatra Mts }\end{array}$ & Moore 1084 & 5 & \\
\hline langii & LN39 & Austria, Steiermark & Moore \& Aoki 1117 & 5 & \\
\hline langii & LN54 & Austria, Niederösterreich & Moore 1065 & 5 & \\
\hline langii & LN56 & Slovakia, Košice, Slovenský raj Mts & Moore 1074 & 5 & \\
\hline langii & LN57 & $\begin{array}{l}\text { Slovakia, Banská Bystrica region, } \\
\text { Muránska planina Mts }\end{array}$ & Moore \& Blanár 1073 & 5 & \\
\hline langii & LN58 & $\begin{array}{l}\text { Slovakia, Žilina, near Liptovská } \\
\text { Lúžna }\end{array}$ & Moore \& Turis 1079 & 5 & \\
\hline langii & LN59 & $\begin{array}{l}\text { Slovakia, Žilina, Krivánska Malá } \\
\text { Fatra Mts }\end{array}$ & Moore 1083 & 4 & \\
\hline
\end{tabular}

Species, population code, sampling locality, voucher information, number of individuals included in the final dataset $(\mathrm{N})$, and presence in the Taxon dataset $(\mathrm{T})$. All vouchers are deposited at MJG, unless otherwise noted. 


\begin{tabular}{|c|c|c|c|c|c|}
\hline species & code & locality & collection & $\mathbf{N}$ & $\mathrm{T}$ \\
\hline langii & LN60 & $\begin{array}{l}\text { Slovakia, Trečin, Strážovské vrchy } \\
\text { Mts }\end{array}$ & Moore et al. 1086 & 4 & \\
\hline langii & LN61 & Austria, Niederösterreich & Moore 1092 & 5 & \\
\hline langii & LN71 & Slovakia, Žilina, Nízke Tatry Mts & Moore \& Turis 1080 & 5 & \\
\hline langii & LN72 & Slovakia, Žilina, Chočské vrchy Mts & Moore \& Turis 1081 & 3 & \\
\hline langii & LN74 & Slovakia, Košice, Slovenský raj Mts & Moore \& Dražil 1077 & 5 & \\
\hline langii & LN76 & $\begin{array}{l}\text { Slovakia, Trečin, Strážovské vrchy } \\
\text { Mts }\end{array}$ & $\begin{array}{l}\text { Moore \& Smatanová } \\
1088\end{array}$ & 4 & \\
\hline langii & LN77 & $\begin{array}{l}\text { Slovakia, Žilina, Strážovské vrchy } \\
\text { Mts }\end{array}$ & $\begin{array}{l}\text { Moore \& Smatanová } \\
1089\end{array}$ & 2 & * \\
\hline langii & LN79 & $\begin{array}{l}\text { Slovakia, Trečin, Strážovské vrchy } \\
\text { Mts }\end{array}$ & $\begin{array}{l}\text { Moore \& Smatanová } \\
1091\end{array}$ & 5 & \\
\hline langii & LN80 & Austria, Niederösterreich & Moore 1112 & 5 & \\
\hline $\begin{array}{l}\text { laricifolia subsp. } \\
\text { laricifolia }\end{array}$ & LL40 & Italy, Südtirol, Bozen & Moore \& Aoki 1134 & 5 & \\
\hline $\begin{array}{l}\text { laricifolia subsp. } \\
\text { laricifolia }\end{array}$ & LL41 & Italy, Südtirol, Bozen & Moore \& Aoki 1155 & 5 & \\
\hline $\begin{array}{l}\text { laricifolia subsp. } \\
\text { laricifolia }\end{array}$ & LL42 & Switzerland, Graubünden & Kadereit s.n. & 5 & \\
\hline $\begin{array}{l}\text { laricifolia subsp. } \\
\text { laricifolia }\end{array}$ & LL47 & France, Rhône-Alpes, Isère & Moore et al. 1202 & 5 & \\
\hline $\begin{array}{l}\text { laricifolia subsp. } \\
\text { laricifolia }\end{array}$ & LL49 & France, Rhône-Alpes, Isère & Moore et al. 1210 & 5 & * \\
\hline $\begin{array}{l}\text { laricifolia subsp. } \\
\text { laricifolia }\end{array}$ & LL55 & Switzerland, Wallis & Moore et al. 1178 & 5 & \\
\hline $\begin{array}{l}\text { laricifolia subsp. } \\
\text { laricifolia }\end{array}$ & LL62 & Austria, Tirol & Moore \& Aoki 1119 & 4 & \\
\hline $\begin{array}{l}\text { laricifolia subsp. } \\
\text { laricifolia }\end{array}$ & LL65 & $\begin{array}{l}\text { France, Provence-Alpes-Côte d'Azur, } \\
\text { Alpes de Haute Provence }\end{array}$ & Moore et al. 1245 & 5 & \\
\hline $\begin{array}{l}\text { laricifolia subsp. } \\
\text { laricifolia }\end{array}$ & LL66 & $\begin{array}{l}\text { France, Provence-Alpes-Côte d'Azur, } \\
\text { Alpes Maritimes }\end{array}$ & Moore \& Ichter 1252 & 4 & \\
\hline $\begin{array}{l}\text { laricifolia subsp. } \\
\text { laricifolia }\end{array}$ & LL67 & $\begin{array}{l}\text { France, Provence-Alpes-Côte d'Azur, } \\
\text { Alpes Maritimes }\end{array}$ & Moore \& Ichter 1268 & 5 & \\
\hline
\end{tabular}

Species, population code, sampling locality, voucher information, number of individuals included in the final dataset $(\mathrm{N})$, and presence in the Taxon dataset $(\mathrm{T})$. All vouchers are deposited at MJG, unless otherwise noted. 


\begin{tabular}{|c|c|c|c|c|c|}
\hline species & code & locality & collection & $\mathbf{N}$ & $T$ \\
\hline $\begin{array}{l}\text { laricifolia subsp. } \\
\text { laricifolia }\end{array}$ & LL68 & Italy, Piemonte, Cuneo & Moore et al. 1291 & 5 & \\
\hline $\begin{array}{l}\text { laricifolia subsp. } \\
\text { laricifolia }\end{array}$ & LL85 & Italy, Südtirol, Bozen & Moore \& Aoki 1152 & 4 & \\
\hline $\begin{array}{l}\text { laricifolia subsp. } \\
\text { laricifolia }\end{array}$ & LL86 & Switzerland, Wallis & Moore et al. 1187 & 4 & \\
\hline $\begin{array}{l}\text { laricifolia subsp. } \\
\text { laricifolia }\end{array}$ & LL88 & $\begin{array}{l}\text { France, Provence-Alpes-Côte d'Azur, } \\
\text { Hautes Alpes }\end{array}$ & Moore et al. 1232 & 4 & \\
\hline $\begin{array}{l}\text { laricifolia subsp. } \\
\text { laricifolia }\end{array}$ & LL89 & $\begin{array}{l}\text { France, Provence-Alpes-Côte d'Azur, } \\
\text { Hautes Alpes }\end{array}$ & Moore et al. 1234 & 5 & \\
\hline $\begin{array}{l}\text { laricifolia subsp. } \\
\text { laricifolia }\end{array}$ & LL92 & $\begin{array}{l}\text { France, Provence-Alpes-Côte d'Azur, } \\
\text { Alpes Maritimes }\end{array}$ & Moore \& Ichter 1260 & 4 & \\
\hline $\begin{array}{l}\text { laricifolia subsp. } \\
\text { laricifolia }\end{array}$ & LL95 & $\begin{array}{l}\text { France, Provence-Alpes-Côte d'Azur, } \\
\text { Alpes Maritimes }\end{array}$ & Moore \& Ichter 1278 & 2 & \\
\hline $\begin{array}{l}\text { laricifolia subsp. } \\
\text { laricifolia }\end{array}$ & LL96 & $\begin{array}{l}\text { France, Provence-Alpes-Côte d'Azur, } \\
\text { Alpes Maritimes }\end{array}$ & Moore 1288 & 5 & \\
\hline $\begin{array}{l}\text { laricifolia subsp. } \\
\text { laricifolia }\end{array}$ & LL98 & Italy, Piemonte, Cuneo & Moore et al. 1299 & 5 & \\
\hline $\begin{array}{l}\text { laricifolia subsp. } \\
\text { laricifolia }\end{array}$ & LL99 & Switzerland, Tessin & Moore et al. 1300 & 5 & \\
\hline $\begin{array}{l}\text { laricifolia subsp. } \\
\text { laricifolia }\end{array}$ & LL218 & $\begin{array}{l}\text { France, Languedoc-Roussillon, } \\
\text { Lozère }\end{array}$ & Moore \& Klein 1449 & 5 & \\
\hline $\begin{array}{l}\text { laricifolia subsp. } \\
\text { laricifolia }\end{array}$ & LL219 & $\begin{array}{l}\text { France, Languedoc-Roussillon, } \\
\text { Lozère }\end{array}$ & Moore \& Klein 1450 & 3 & \\
\hline $\begin{array}{l}\text { laricifolia subsp. } \\
\text { laricifolia }\end{array}$ & LL220 & $\begin{array}{l}\text { France, Languedoc-Roussillon, } \\
\text { Pyrénées-Orientales }\end{array}$ & Moore \& Klein 1455 & 5 & \\
\hline $\begin{array}{l}\text { laricifolia subsp. } \\
\text { laricifolia }\end{array}$ & LL273 & France, Rhône-Alpes, Haute Savoie & $\begin{array}{l}\text { Moore \& Dillenberger } \\
1551\end{array}$ & 5 & \\
\hline $\begin{array}{l}\text { laricifolia subsp. } \\
\text { ophiolitica }\end{array}$ & L050 & Italy, Liguria, Genova & Moore 1031 & 5 & * \\
\hline $\begin{array}{l}\text { laricifolia subsp. } \\
\text { ophiolitica }\end{array}$ & L051 & Italy, Liguria, Genova & Moore 1025 & 5 & \\
\hline $\begin{array}{l}\text { laricifolia subsp. } \\
\text { ophiolitica }\end{array}$ & L052 & Italy, Emilia-Romagna, Parma & Moore 1038 & 5 & \\
\hline
\end{tabular}

\footnotetext{
Species, population code, sampling locality, voucher information, number of individuals included in the final dataset $(\mathrm{N})$, and presence in the Taxon dataset $(\mathrm{T})$. All vouchers are deposited at MJG, unless otherwise noted.
} 


\begin{tabular}{|c|c|c|c|c|c|}
\hline species & code & locality & collection & $\mathbf{N}$ & $\mathrm{T}$ \\
\hline parnonia & PA & Greece, Peloponnisos, Arkadia & $\begin{array}{l}\text { Kalpoutzakis } 2022 \\
\text { (ACA) }\end{array}$ & 4 & \\
\hline parnonia & PA229 & Greece, Peloponnisos, Arkadia & $\begin{array}{l}\text { Moore \& } \\
\text { Anastopoulos } 1512\end{array}$ & 1 & * \\
\hline rupestris & LA237 & Lebanon, Beqaa & Tohmé s.n. & 5 & * \\
\hline sedoides & SE152 & France, Rhône-Alpes, Isère & Moore et al. 1203 & 1 & * \\
\hline sedoides & SE46 & Austria, Tirol & Moore \& Aoki 1133 & 1 & \\
\hline wettsteinii & WE & Greece, Crete: Lasithi & $\begin{array}{l}\text { Papasotiropoulos \& } \\
\text { Trigas, DNA } 2.11\end{array}$ & 5 & $\mathrm{x}$ \\
\hline \multicolumn{6}{|c|}{$\begin{array}{l}\text { Species, population code, sampling locality, voucher information, number of individuals included in } \\
\text { the final dataset }(N) \text {, and presence in the Taxon dataset }(T) \text {. All vouchers are deposited at MJG, unless } \\
\text { otherwise noted. }\end{array}$} \\
\hline
\end{tabular}

\section{Tree-based Analyses:}

\section{RAXML nrDNA tree}

The nrDNA tree for the populations sampled in this study (Fig. 1) was congruent with the wider sampling from Moore and Kadereit (2013). Plants were divided into a calcifuge clade (C. baldaccii (Halácsy) A.J. Moore \& Dillenb., C. garckeana (Asch. \& Sint. ex Boiss.) A.J. Moore \& Dillenb., and C. laricifolia; $99 \%$ bootstrap support, BS), a calcicole clade ( $C$. langii and the French populations of $C$. capillacea (All.) A.J. Moore \& Dillenb.; 98\% BS), and a clade containing the Greek endemics (C. dirphya (Trigas \& latroú) A.J. Moore \& Dillenb., C. parnonia (Kamari) A.J. Moore \& Dillenb., and C. wettsteinii (Mattf.) A.J. Moore \& Dillenb.; $94 \%$ BS). The relationships among these three groups and the samples of Albanian C. capillacea, C. doerfleri (Hayek) A.J. Moore \& Dillenb., and C. sedoides were not resolved.

\section{RAXML GBS tree}

In the RAxML tree of the concatenated GBS data (Population dataset, Fig. S1), all species for which we had multiple samples were well supported as monophyletic with $100 \%$ bootstrap support, except for $C$. capillacea. In C. capillacea, the three French populations were monophyletic with $100 \%$ bootstrap support, but the Albanian population was separate. The Greek endemic species formed a clade $(C$. dirphya, $C$. parnonia, and $C$. wettsteinii; $98 \%$ BS). The three calcifuge species also formed a clade ( $C$. baldaccii, $C$. garckeana, and C. laricifolia; $97 \%$ BS), with $C$. garckeana sister to $C$. laricifolia (97\% BS). These calcifuge species formed a clade with the Albanian C. capillacea (pop. 223) and the Greek endemic clade $(100 \%$ BS). Relationships within $C$. laricifolia and $C$. langii were generally not supported, with the exception of the three $C$. laricifolia samples from the Pyrenees/Massif Central (pops. 218, 219, and 220; 99\% BS), and a few sister species pairs. 


\section{SVDQuartets}

When SVDQuartets was used to make a species tree from the Population dataset (the dataset composed of the best individual in each population; Fig. S2), C. laricifolia and C. garckeana were sister (99.8\% BS). The third calcifuge species, $C$. baldaccii, was sister to the Albanian population of $C$. capillacea (pop. 223) with no support. These two clades were sister (83.5\% BS). The three Greek endemic species formed a clade (98.5\% BS). These two clades (calcifuge plus Albanian C. capillacea and Greek endemic) were sister ( $99.1 \% \mathrm{BS})$, but the relationships among the remaining species were not supported.

When a species-tree analysis was run on the Individual dataset (the dataset composed of all individuals; Fig. S3), most of the same relationships were supported, except that the calcifuge species formed a clade (88.5\% BS) and the Albanian population of $C$. capillacea (pop. 223) was sister to this calcifuge clade plus the Greek endemics $(99.9 \%$ BS for the entire clade and $85.5 \%$ BS for the clade without Albanian $C$. capillacea).

To evaluate species monophyly, analyses were also run in which populations, instead of species, were the terminal taxa (called population trees). For the population tree from the Population dataset, most species for which multiple populations were sampled were recovered as monophyletic (Fig. S4): C. garckeana (92.9\% BS), C. langii (100.0\% BS), C. laricifolia (71.1\% BS), C. parnonia (95.9\% BS), and C. sedoides (95.4\% BS). There were two exceptions: In C. capillacea, the three French populations grouped together (99.6\% BS), but were separated from the Albanian population (233). In C. baldaccii, population 231 formed a clade with $C$. garckeana and $C$. laricifolia ( $80.8 \%$ BS), while population 232 was the unsupported sister group of Albanian $C$. capillacea. These two clades were part of a larger clade that also included the three Greek endemic species (93.2\% BS for the Greek endemics and $99.1 \%$ BS for the larger clade). There were two main clades within C. laricifolia: one composed of the southern Massif Central and Pyrenees samples (pops. 218, 219, and 220; 94.8\% BS) and one of the rest (73.7\% BS). None of the other relationships within $C$. laricifolia was supported by bootstrap values greater than $70 \%$.

When the Individual dataset was used to construct a population-level tree, all but two species for which multiple individuals were sampled were well supported (Fig. 2). Once again, the Albanian population of $C$. capillacea (pop. 233) was clearly separate from the remaining three populations; instead, it was highly supported as the sister to the calcifuge and Greek endemic plants (98.0\% BS). In addition, C. Iaricifolia was divided into two well-supported sister clades whose relationships to one another were not supported. One of the clades was composed of the three populations from the Massif Central and Pyrenees (pops. 218,219 , and $220 ; 99.5 \%$ BS) and the other contained all remaining plants, including all three populations of subsp. ophiolitica (94.3\% BS). Cherleria garckeana (99.6\% BS) was again sister to C. laricifolia, but with lower support (74.4\% BS). In contrast to the analysis of the Population dataset, $C$. baldaccii was monophyletic ( $90.6 \% \mathrm{BS})$, but was the unsupported sister to the Greek endemic clade, instead of to $C$. garckeana and C. laricifolia. The Greek endemic clade was monophyletic (88.0\% BS), with C. parnonia (100.0\% BS) sister to $C$. wettsteinii, with $80.8 \%$ BS. Both $C$. langii $(100.0 \% \mathrm{BS})$ and the French populations of $C$. capillacea $(99.8 \%)$ were well supported as monophyletic. 


\section{SplitsTree}

In the SplitsTree analyses, relationships were generally congruent with those in the SVDQuartets analyses. In the tree from the Taxon dataset (Fig. S5), C. baldaccii, C. garckeana, and C. laricifolia formed a moderately supported clade $(86.4 \%$ BS). The two subspecies of $C$. laricifolia were also supported as a group (100\% BS). The three Greek endemics (C. dirphya, C. parnonia, and C. wettsteinii) formed a strongly supported group ( $99.2 \% \mathrm{BS}$ ). These two clades and the Albanian population of $C$. capillacea (233) grouped together $(94.5 \%$ BS), as did $C$. langii and the French $C$. capillacea $(92.5 \%)$. There was also some conflict in the data. Within the calcifuge clade, $C$. garckeana grouped alternatively with $C$. baldaccii (79.4\%) or with C. Iaricifolia (85.8\%), and, within the Greek endemic clade, C. parnonia grouped alternatively with $C$. wettsteinii $(70.8 \%)$ or with C. dirphya (96.9\%).

In the tree from the Population dataset (Fig. S6), C. baldaccii, C. garckeana, C. langii, C. sedoides, and the French populations of $C$. capillacea were all supported as monophyletic. Although $C$. parnonia was not supported as monophyletic by itself, the clade of all three Greek endemics was (92.3\%). The calcifuge species and the Greek endemics together formed a clade with the Albanian $C$. capillacea population (92.9\% BS). In addition to being unsupported as monophyletic, C. laricifolia was subtended by a very wide branch. Within $C$. laricifolia, the Pyrenean/Massif Central populations grouped together (97.9\% BS), while the three populations of subsp. ophiolitica were mixed with the populations of Alpine subsp. laricifolia. Cherleria baldaccii was also on a very wide branch, although it was highly supported as monophyletic (100\% BS). However, one of the populations of $C$. baldaccii also grouped with $C$. garckeana, C. Iaricifolia, and one population of $C$. parnonia with high support ( $92.8 \%$, could not show split on figure).

\section{Single Nucleotide Polymorphism (SNP)-based analyses:}

Adegenet for all individuals: Only the Individual dataset was analyzed (Table 2). When the plants were divided into two groups (Fig. S7a), the composition of the groups was the same in all ten runs: The first group contained all individuals of $C$. doerfleri, $C$. langii, and $C$. sedoides, as well as the three non-Albanian populations of $C$. capillacea, and the second contained the remaining plants. Although the composition of the two groups did not vary between runs, only the first group had a large support value (a-score, 0.863 $\pm 0.025)$, while the second group had a very small a-score $(0.036 \pm 0.008)$. 
Table 2

Groups recovered in the adegenet analyses of all individuals.

\begin{tabular}{|c|c|c|c|c|c|c|}
\hline & 2 Groups & $\stackrel{3}{\text { Groups }}$ & $\begin{array}{l}4 \\
\text { Groups }\end{array}$ & $\begin{array}{l}5 \\
\text { Groups }\end{array}$ & $\begin{array}{l}6 \\
\text { Groups }\end{array}$ & $\begin{array}{l}7 \\
\text { Groups }\end{array}$ \\
\hline laricifolia & & $\begin{array}{l}10 \\
0.174 \pm \\
0.018\end{array}$ & $\begin{array}{l}9,0.117 \\
\pm 0.021\end{array}$ & $\begin{array}{l}10, \\
0.109 \pm \\
0.012\end{array}$ & $\begin{array}{l}7, \\
0.105 \pm \\
0.016\end{array}$ & $\begin{array}{l}3, \\
0.137 \pm \\
0.025\end{array}$ \\
\hline $\mathrm{PMC}^{1}$ laricifolia & & & & & $\begin{array}{l}2, \\
0.913 \pm \\
0.021\end{array}$ & $\begin{array}{l}7, \\
0.918 \pm \\
0.012\end{array}$ \\
\hline Non-PMC laricifolia & & & & & $\begin{array}{l}2, \\
0.163 \pm \\
0.017\end{array}$ & $\begin{array}{l}6, \\
0.155 \pm \\
0.014\end{array}$ \\
\hline langii & & $\begin{array}{l}3,0.859 \\
\pm 0.021\end{array}$ & $\begin{array}{l}10 \\
0.836 \pm \\
0.035\end{array}$ & $\begin{array}{l}10 \\
0.820 \pm \\
0.033\end{array}$ & $\begin{array}{l}9, \\
0.800 \pm \\
0.105\end{array}$ & $\begin{array}{l}9, \\
0.765 \pm \\
0.084\end{array}$ \\
\hline non-Albanian capillacea & & & $\begin{array}{l}7,0.932 \\
\pm 0.035\end{array}$ & $\begin{array}{l}10 \\
0.927 \pm \\
0.019\end{array}$ & $\begin{array}{l}7 \\
0.926 \pm \\
0.037\end{array}$ & $\begin{array}{l}7, \\
0.927 \pm \\
0.028\end{array}$ \\
\hline $\begin{array}{l}\text { langii, non-Albanian } \\
\text { capillacea }\end{array}$ & & $\begin{array}{l}7,0.728 \\
\pm 0.031\end{array}$ & & & & \\
\hline baldaccii & & & & $1,0.918$ & $\begin{array}{l}6, \\
0.897 \pm \\
0.016\end{array}$ & $\begin{array}{l}8, \\
0.918 \pm \\
0.030\end{array}$ \\
\hline garckeana & & & & $\begin{array}{l}3,0.949 \\
\pm 0.017\end{array}$ & $\begin{array}{l}9, \\
0.941 \pm \\
0.024\end{array}$ & $\begin{array}{l}9, \\
0.933 \pm \\
0.028\end{array}$ \\
\hline baldaccii, garckeana & & & $\begin{array}{l}3,0.934 \\
\pm 0.145\end{array}$ & $\begin{array}{l}6,0.951 \\
\pm 0.018\end{array}$ & $1,0.921$ & \\
\hline 3 Greek endemics & & & & & $1,0.950$ & $\begin{array}{l}3, \\
0.926 \pm \\
0.017\end{array}$ \\
\hline $\begin{array}{l}3 \text { Greek endemics, Albanian } \\
\text { capillacea }\end{array}$ & & & & & $1,0.979$ & $\begin{array}{l}3, \\
0.933 \pm \\
0.005\end{array}$ \\
\hline $\begin{array}{l}\text { doerfleri, langii, sedoides, } \\
\text { non-Albanian capillacea }\end{array}$ & $\begin{array}{l}10 \\
0.863 \pm \\
0.025\end{array}$ & & & & & \\
\hline
\end{tabular}

${ }^{1}$ PMC is Pyrenees/Massif Central

Only groups recovered from more than one total run are shown. Each cell contains the number of runs (from 1 to 10) in which that group was recovered, followed by the mean and standard deviation of the a-score for that group. 


\begin{tabular}{|c|c|c|c|c|c|c|}
\hline & 2 Groups & $\begin{array}{l}3 \\
\text { Groups }\end{array}$ & $\stackrel{4}{\text { Groups }}$ & $\begin{array}{l}5 \\
\text { Groups }\end{array}$ & $\begin{array}{l}6 \\
\text { Groups }\end{array}$ & $\begin{array}{l}7 \\
\text { Groups }\end{array}$ \\
\hline remaining plants & $\begin{array}{l}10, \\
0.036 \pm \\
0.008\end{array}$ & & & & & \\
\hline $\begin{array}{l}\text { remaining plants (with non- } \\
\text { Albanian capillacea) }\end{array}$ & & $\begin{array}{l}3,0.790 \\
\pm 0.019\end{array}$ & & & & \\
\hline $\begin{array}{l}\text { remaining plants (without } \\
\text { non-Albanian capillacea) }\end{array}$ & & $\begin{array}{l}7,0.886 \\
\pm 0.022\end{array}$ & & & & \\
\hline \multicolumn{7}{|c|}{${ }^{1} \mathrm{PMC}$ is Pyrenees/Massif Central } \\
\hline \multicolumn{7}{|c|}{$\begin{array}{l}\text { Only groups recovered from more than one total run are shown. Each cell contains the number of runs } \\
\text { (from } 1 \text { to 10) in which that group was recovered, followed by the mean and standard deviation of the } \\
\text { a-score for that group. }\end{array}$} \\
\hline
\end{tabular}

When the plants were divided into three groups (Fig. S7b), one group always consisted of $C$. laricifolia, but had low support $(0.174 \pm 0.018)$. The second group consisted of $C$. langii either by itself or with the non-Albanian populations of $C$. capillacea. When the plants were divided into four groups (Fig. S7c), the only group that was present in all runs was $C$. langii. The two other common groups were $C$. laricifolia and the non-Albanian C. capillacea. When the plants were divided into five groups (Fig. S7d), three groups were always present: $C$. langii, $C$. laricifolia, and the non-Albanian $C$. capillacea. The remaining group (besides the group consisting of the leftover populations), was either $C$. baldaccii, $C$. garckeana, or the group formed of both $C$. baldaccii and $C$. garckeana. When the plants were divided into six groups (Fig. S7e), no groups were present in all ten runs. The two most common groups were $C$. langii and $C$. garckeana. Cherleria laricifolia sometimes formed a single group and sometimes the three Pyrenees/Massif Central populations were separated from the remaining populations. The other two common groups were $C$. baldaccii and the non-Albanian populations of $C$. capillacea. When the plants were divided into seven groups (Fig. S7f), the two most common groups were once again $C$. langii and $C$. garckeana. Cherleria laricifolia was more commonly broken up into the Pyrenees/Massif Central populations and the remaining populations than it was recovered as a single group. The other common groups were $C$. baldaccii, the non-Albanian populations of $C$. capillacea, and the three Greek endemic species ( $C$. dirphya, $C$. parnonia, and $C$. wettsteinii), either with or without the Albanian population of $C$. capillacea.

Looking at admixture, there were no individuals that had a posterior probability more than 0.90 of being in multiple groups for the analyses in which the plants were divided into two, three, or four groups. For the remaining analyses, the only runs in which admixed individuals were found were those in which $C$. langii was divided into two groups (once each for the divisions into six and seven groups) or when the nonPyrenees/Massif Central populations of $C$. laricifolia were divided into two groups (also once each for the divisions into six and seven groups). In these cases, some individuals showed admixture between these groups. 


\section{Adegenet for Cherleria langii alone}

When $C$. langii was analyzed alone, the results were quite consistent from run to run (Table 3 ). When the plants were divided into two groups (Fig. S8), one group consisted of the populations from Slovakia, while the other consisted of the populations from Austria. When the plants were divided into three groups (Fig. 3), the Austrian group persisted, while the southernmost Slovakian population from Mt. Hradovà (pop. 57) was separated from the remaining Slovakian populations.

Table 3

Groups recovered in the adegenet analyses of Cherleria langii alone.

\begin{tabular}{|lll|}
\hline & 2 Groups & 3 Groups \\
\hline Austrian langii & $10,0.792 \pm 0.031$ & $10,0.774 \pm 0.038$ \\
\hline Slovakian langii & $10,0.050 \pm 0.012$ & \\
\hline Slovakian langii without LN75 & & $10,0.068 \pm 0.015$ \\
\hline LN75 & & $10,0.836 \pm 0.046$ \\
\hline
\end{tabular}

Each cell contains the number of runs (10 in all cases) in which that group was recovered, followed by the mean and standard deviation of the a-score for that group.

Adegenet for Cherleria laricifolia alone: When $C$. laricifolia was analyzed alone, the results were also more consistent from run to run than when all taxa were analyzed together (Table 4). In all runs in which the individuals were divided into two groups (Fig. S9a), the Pyrenees/Massif Central populations were separated from the remaining populations, which were much more poorly supported. When the individuals were divided into three clusters (Fig. S9b), The Pyrenees/Massif Central populations were also present in every run. In seven cases, the remaining plants were divided into subsp. ophiolitica and the rest of subsp. laricifolia. In three cases, subsp. ophiolitica was combined with most of the French populations of subsp. laricifolia into one group, while the Italian, Swiss, and Austrian populations together with the north-eastern most French population (from Chamonix, pop. 273) of subsp. laricifolia formed the second group. When the individuals were divided into four clusters (Fig. 4), the same four groups were always present: the Pyrenees/Massif Central populations of subsp. laricifolia, subsp. ophiolitica, the French populations of subsp. laricifolia except for the population from Chamonix (Western Alps populations), and the Italian, Swiss, and Austrian populations of subsp. laricifolia together with the French population from Chamonix (Central Alps populations). 
Table 4

Groups recovered in the adegenet analyses of Cherleria laricifolia alone.

\begin{tabular}{|llll|}
\hline & 2 Groups & 3 Groups & 4 Groups \\
\hline PMC $^{1}$ laricifolia & $10,0.946 \pm$ & $10,0.919 \pm$ & $10,0.891 \pm$ \\
& 0.027 & 0.034 & 0.042 \\
\hline non-PMC laricifolia & $10,0.007 \pm$ & & \\
& 0.003 & & \\
\hline subsp. ophiolitica & & $7,0.929 \pm$ & $10,0.869 \pm$ \\
& & 0.032 & 0.035 \\
\hline non-PMC subsp. laricifolia & & $7,0.014 \pm$ & \\
& & 0.005 & \\
\hline subsp. ophiolitica, French subsp. laricifolia & $3,0.590 \pm$ & \\
& & 0.037 & $10,0.539 \pm$ \\
\hline French subsp. laricifolia & & & 0.031 \\
\hline Italian, Swiss, Austrian subsp. laricifolia (and & $3,0.213 \pm$ & $10,0.283 \pm$ \\
\hline Chamonix) & & 0.016 & 0.023 \\
\hline 1 PMC is Pyrenees/Massif Central & & \\
\hline
\end{tabular}

Each cell contains the number of runs (from 1 to 10) in which that group was recovered, followed by the mean and standard deviation of the a-score for that group.

\section{fineRADstructure}

When all individuals were analyzed together, fineRADstructure recovered all species as their own group, with $C$. capillacea being divided into two groups, one of the non-Albanian populations and one of the Albanian population (Fig. 5). The groups varied in the strength of similarity among their members. The Albanian populations of $C$. capillacea, $C$. doerfleri, $C$. rupestris (Labill.) A.J. Moore \& Dillenb., and $C$. sedoides, along with each of the three Greek endemic species each formed a strong group. Cherleria baldaccii, the French populations of $C$. capillacea, and the group formed by the three Greek endemic species formed moderately strong groups. Cherleria garckeana, $C$. langii, and $C$. laricifolia each formed week groups, with the Pyrenees/Massif Central populations forming a weak group within $C$. laricifolia as a whole.

When $C$. laricifolia was analyzed alone, the Pyrenees/Massif Central populations formed their own group, as they did when all individuals were analyzed together (Fig. S10). In contrast to the analysis of all species, the individuals of subsp. ophiolitica also grouped together. There were several other very weak groups, which corresponded to individual populations. 
When $C$. langii was analyzed alone, there were no strong patterns (Fig. S11). The patterns that existed were largely groupings of the plants from an individual population. The samples as a whole were also weekly grouped by geography, with the Austrian samples forming a weak group, which was separated first.

\section{D-statistics}

The two sets of analyses, those with the groups formed based on the SVDQuartets tree and those with the groups formed based on the RAxML tree, gave congruent results (see Additional file 2). The two species with the most introgression were $C$. garckeana and $C$. laricifolia. They both showed introgression $>5 \%$ with each other, non-Albanian C. capillacea, $C$. parnonia, and the common ancestor of $C$. parnonia and $C$. wettsteinii. In addition, $C$. laricifolia had introgression with $C$. baldaccii and non-Albanian $C$. capillacea showed introgression with $C$. langii (RAxML only). Although there were 149 total significant tests involving $C$. langii and $C$. laricifolia over both trees, this appeared to be because these were the two species with the highest sampling, as no individual had more than $0.3 \%$ of tests significant, and most had $<0.1 \%$ of tests significant.

\section{Species Distribution Modeling:}

Cherleria capillacea: For Cherleria capillacea, the variables used in the final analysis were the following: Bio12 (mean annual precipitation), the variable with the highest gain in isolation; $\mathrm{pH}$, the variable with the greatest unique contribution, when it was included; Bio15 (precipitation seasonality), the variable with the greatest unique contribution, when $\mathrm{pH}$ was not included; Bio5 (maximum temperature of the warmest month), Bio8 (mean temperature of the wettest quarter), and Bio11 (mean temperature of the coldest quarter), all of which had significant contributions or importances; and Bio4 (temperature seasonality), which did not have a significant contribution but was not correlated with other variables.

The values for the area under the receiver operator characteristic (ROC) curve (AUC values) ranged from 0.921-0.945. Congruent with the results of the preliminary analyses, Bio12 (mean annual precipitation) had the greatest individual contribution to the model (percent contribution 42.9-49.1). In contrast to the results of the preliminary analyses, Bio11 (mean temperature of the coldest quarter) had the greatest loss when it was left out, in all but one case (percent importance 26.5-45.2). Bio8 (mean temperature of the wettest quarter) had both the next highest gain in isolation (percent contribution 22.6-25.1). When included, $\mathrm{pH}$ had a relatively small contribution (percent contribution 6.9-9.1).

For $C$. capillacea, both of the current climate models (with and without $\mathrm{pH}$ included) had a high probability of occurrence in the central and western Alps, northern Apennines, Massif Central, Pyrenees, and all along the western side of the Balkan Peninsula from Croatia to Greece (Figs. 6a, S12d). The model without $\mathrm{pH}$ also included potential area of occurrence in south-western Germany. The models with $\mathrm{pH}$ supported an LGM distribution that was more or less equivalent to its current range, as well as areas in north-western France, Poland, and the Ukraine (Figs. S12a-c). However, the occurrence of $C$. capillacea 
in these areas all had a probability $<0.70$. The models without $\mathrm{pH}$ included not having any areas of occurrence with a probability $>0.25$ (Figs. S12e-g).

Cherleria langii: For Cherleria langii, the variables used in the final analysis were the following: Bio18 (precipitation of the warmest quarter), the variable with the highest gain in isolation; Bio8 (mean temperature of the wettest quarter), the variable with the greatest unique contribution, whether or not $\mathrm{pH}$ was included; Bio9 (mean temperature of the driest quarter), Bio12 (mean annual precipitation), Bio15 (precipitation seasonality), and $\mathrm{pH}$ all of which had significant contributions or importances; and Bio2 (mean diurnal temperature range) and Bio4 (temperature seasonality), which did not have significant contributions but were not correlated with other variables.

The AUC values ranged from $0.962-0.969$. Congruent with the results of the preliminary analyses, Bio18 (precipitation of the warmest quarter) had the greatest individual contribution to the model (percent contribution 65-81.9). In contrast to the results of the preliminary analyses, Bio9 (mean temperature of the wettest quarter) had the greatest unique contribution (percent importance of 63.8-77.1). In these analyses, it also had the greatest loss when it was left out, likely due to the omission of the variables with which it was correlated. When $\mathrm{pH}$ was included, it had the next highest gain in isolation (percent contribution 14.7-18.8), while Bio15 (precipitation seasonality) had the second or third highest gain in isolation, depending on whether $\mathrm{pH}$ was present or not (percent contribution 8-9.6). In addition to having the highest gain in isolation, Bio18 had the second highest unique contribution in all but one case (percent importance 9.4-16.5, with an outlying value of 3.5), with Bio12 (mean annual precipitation) having the highest unique contribution in that case (percent importance 11.5 for that model and 5.8-12.8 otherwise).

For $C$. langii, the current distribution was approximately the same with or without $\mathrm{pH}$ included, and corresponded closely to the current distribution of the eastern Alps and Carpathians (Figs. 6b, S13d). The predicted distribution extended farther west than the current distribution, however, as well as into southern Germany. None of the LGM models showed any areas with a probability of occurrence $>0.10$ (Figs. S13a-c, e-g).

Cherleria laricifolia: For Cherleria laricifolia, the variables used in the final analysis were the following: Bio10 (mean temperature of the warmest quarter), the variable with the highest gain in isolation; Bio9 (mean temperature of the driest quarter), the variable with the greatest unique contribution, when $\mathrm{pH}$ was included; Bio19 (precipitation of the coldest quarter), the variable with the greatest unique contribution, when $\mathrm{pH}$ was not included; Bio8 (mean temperature of the wettest quarter), which also had a significant contribution; and Bio2 (mean diurnal temperature range), Bio4 (temperature seasonality), Bio17 (precipitation of the driest quarter), and $\mathrm{pH}$, which did not have significant contributions but were not correlated with other variables.

The AUC values ranged from 0.964-0.973. Congruent with the results of the preliminary analyses, Bio10 (mean temperature of the warmest quarter) had the greatest individual contribution to the model (percent contribution 68-69). In these analyses, it also had the greatest loss when it was left out, likely due to the 
omission of the variables with which it was correlated (percent importance of 45.8-55.8). Bio8 (mean temperature of the wettest quarter) had the next highest gain in isolation (percent contribution 11.614.1), while Bio17 (precipitation of the driest quarter) and Bio4 (temperature seasonality) had the second highest unique contribution (Bio17, 4 models, 10.4-16.8; Bio4, 2 models, 6.3-15.8). When included, $\mathrm{pH}$ had a relatively small contribution (percent contribution $5.8-6.1$ ).

For $C$. laricifolia, both of the current climate models (with and without $\mathrm{pH}$ included) had a range that included its current range in the western and central Alps, the Massif Central, the Pyrenees, and the northern Apennines, with additional occurrence probabilities in the northern part of the Balkan Peninsula, the central Alps, and the Carpathians (Figs. 6c, S14d). Standard deviations between model runs were very low across the entire range. None of the LGM models showed probabilities of occurrence $>0.10$ (Figs. S14a-c, e-g).

\section{Discussion}

\section{Phylogeny of Cherleria comparison of nrDNA and GBS data}

With respect to interspecific phylogenetic relationships, the GBS results presented here were largely congruent with the nrDNA results obtained in an earlier analysis (Moore and Kadereit 2013), despite the fact that the GBS data integrate over a much larger portion of the genome and that each individual locus is much less informative. However, the GBS data also show that the evolution of Cherleria was more complicated than inferred from nrDNA data, with several instances of gene flow. The possible evolutionary significance of gene flow will be discussed in detail below.

The present study included all members of Clade $C$ (the Alpine/Balkan clade) of our previous analysis based on nrDNA sequence data (Moore and Kadereit 2013; Fig. 1) except for $C$. handelii, for which we could not obtain fresh material. In the nrDNA data, all species for which multiple individuals were sampled were resolved as monophyletic, except for $C$. capillacea, in which the Albanian population was separate from the remaining populations. The nrDNA data grouped the plants sampled here into three subclades: a subclade of calcifuge species (C. baldaccii, $C$. garckeana, C. laricifolia), a subclade of calcicole species ( $C$. capillacea, $C$. handelii, $C$. langii), and a subclade containing three narrow endemics from Greece ( $C$. dirphya, $C$. parnonia, $C$. wettsteinii). The two remaining species, $C$. doerfleri and $C$. sedoides, had uncertain positions within Clade C. Cherleria rupestris (M. labillardierei), the outgroup in this study, was outside of Clade $C$ in the nrDNA tree.

Both tree (Figs. 2, S2, S3, S4) and network (Figs. S5, S6) analyses of the GBS data also showed most species to be monophyletic. The exceptions were $C$. capillacea and $C$. baldaccii. In $C$. capillacea, the Albanian population again grouped separately from the rest. The type locality of $C$. capillacea is the Col de Tende, on the border between France and Italy in the western Alps (Allioni 1785). Thus, when the species is split, the name $C$. capillacea belongs with the western/northern populations. Therefore, core $C$. capillacea, represented by three French populations in the present study, but also including samples from 
Italy and Bosnia-Herzegovina in the nrDNA analyses (Moore and Kadereit 2013), will be referred to henceforth as $C$. capillacea s.s. The other group will be referred to as Albanian $C$. capillacea, even though it is possible that the range of that species extends outside of Albania. The boundary between $C$. capillacea s.s. and Albanian C. capillacea remains unclear, due to limited sampling. In C. baldaccii, the two populations sampled in this study were sometimes not sister to each other, but monophyly of the species was also not consistently supported in the nrDNA analysis (Moore and Kadereit 2013).

In $C$. langii and $C$. laricifolia, intraspecific relationships found here differ somewhat from those found by Moore \& Kadereit (2013). In C. langii, the present analysis revealed more intraspecific phylogenetic structure than our earlier nrDNA analysis (Moore and Kadereit 2013). Although there were no strongly supported groups within this species in the phylogenetic analyses of the GBS data, the plants were divided into Austrian populations (from the Alps) and Slovakian populations (from the Carpathians) in adegenet (Figs. 3, S8) and fineRADstructure (Fig. S11). Within C. laricifolia, the populations from the Pyrenees and the Massif Central strongly grouped together in SVDQuartets (Figs. 2, S4), SplitsTree (Fig. S6), adegenet (Figs. 4, S9), and fineRADstructure (Fig. S10). Relationships of this group to the remainder of the species differed among analyses. These populations were separated as $C$. laricifolia subsp. diomedis (Braun-Blanquet) A.J. Moore \& Dillenb., due to the presence of glandular hairs. However, this character is somewhat variable within populations (L. Sáez Goñalons, Universidad Autónoma de Barcelona, personal communications), and this group is often included within subsp. laricifolia (e.g., Halliday 1993). Subspecies ophiolitica also formed its own group in many of the adegenet runs (Figs. 4, S9) and in fineRADstructure (Fig. S10). When it was not a separate group, it grouped with the populations of subsp. Iaricifolia from the Maritime Alps and elsewhere in France, which is congruent with its sharing of chloroplast haplotypes with the Maritime Alps populations of subsp. laricifolia (Moore et al. 2013). The Alpine populations of subsp. laricifolia were also sometimes divided into Western Alps and Central Alps groups in the adegenet analyses (Fig. 4), congruent with our previous AFLP results (Moore et al. 2013).

Of the major clades found with the nrDNA data, the GBS data resolved a well-supported clade containing the three narrow endemics from Greece. The subclade of calcifuge species was also sometimes recovered, although one or both of the populations of $C$. baldaccii often grouped separately from the rest of the calcifuge clade. The two sampled species from the calcicole subclade, $C$. capillacea and $C$. langii, never grouped together exclusively, in part because Albanian $C$. capillacea was separated from $C$. capillacea s.s. However, even without Albanian $C$. capillacea, the clade formed by $C$. langii and $C$. capillacea s.s. was never strongly supported. In contrast to the nrDNA data, in which the relationships among the subclades of Clade $\mathrm{C}$ were not resolved, the GBS data showed that the Greek endemics, the calcifuge species, and Albanian $C$. capillacea grouped together with strong support.

\section{Evolutionary significance of interspecific gene flow in Cherleria}


Although the GBS data thus clearly did not recover fundamentally different relationships from those found with the nrDNA data, several of our analyses point to interspecific hybridization in the evolutionary history of Cherleria. Cherleria laricifolia in particular 1) had low bootstrap support in SVDQuartets (Fig. 2) and the topology of the SVDQuartets tree differed from that of the RAxML tree of the GBS data (Fig. S1). 2) The branch subtending $C$. laricifolia in the SplitsTree analyses was quite wide, indicating multiple divergent histories in the data, and the species was not supported in those analyses (Fig. S6). 3) The group formed by $C$. laricifolia in both fineRADstructure (Fig. 5) and adegenet (Fig. S7; Table 2) was always diffuse or poorly supported. 4) Most importantly, direct tests of hybridization using $D_{\text {FOIL }}$ recovered evidence that several different species hybridized with $C$. laricifolia, namely $C$. baldaccii, $C$. capillacea s.s., C. garckeana, $C$. parnonia, and the common ancestor of $C$. parnonia and $C$. wettsteinii (Table 5). Although the species involved in hybridization with $C$. laricifolia were the same whether the SVDQuartets tree or the RAXML tree was used as the basis for choosing groups, the amount of hybridization inferred for each population of $C$. laricifolia varied in the two sets of analyses. These differences were likely due to the differences in topology between the two trees, with the most dramatic being that the Pyrenees/Massif Central populations were sister to the remainder of $C$. laricifolia in the SVDQuartets trees (Figs. 2, S4) and were nested within C. laricifolia in the RAxML tree (Fig. S1).

In contrast to the situation with $C$. laricifolia, where low support for its monophyly indicated inconsistencies with a strictly branching scenario, $C$. garckeana and $C$. langii formed better supported, tighter groupings in all trees and analyses (Figs. 2, 5, S4, S6), and we would not have suspected hybridization in the absence of explicit tests for it. However, $D_{\text {FOIL }}$ tests also detected hybridization between $C$. garckeana and $C$. capillacea s.s., $C$. laricifolia, $C$. parnonia, and the common ancestor of $C$. parnonia and $C$. wettsteinii and between $C$. langii and both $C$. baldaccii and $C$. capillacea s.s. (Table 5). Thus, detectable hybridization appears to take place both in parts of the phylogenetic tree where it could be predicted from features of the tree and in other parts where it could not be predicted, without explicitly testing for it. Assuming only a relatively small percentage of the loci were of hybrid origin, and the remaining loci were congruent in supporting a single topology because the group has otherwise had a relatively long independent history, then hybridization could still be evolutionarily significant, while having minimal impact on the reconstructed species tree. Similar scenarios have been found in South American siskins (Beckman et al. 2018) and Sceloporus lizards (Lambert et al. 2019).

Hybridization among closely related species is hypothesized to enlarge the gene pool of potentially adaptive loci and allow groups to undergo rapid morphological or ecological radiation or range expansion (Abbott et al. 2013, Whitney et al. 2015, Pfenning et al. 2016, Grant and Grant 2019, Marques et al 2019). Examples of specific known genes that have been transferred by hybridization include genes for wing pattern in Heliconius (Pardo-Diaz 2012), flower color in the Diplacus aurantiacus complex (formerly Mimulus aurantiacus; Stankowski and Striesfeld 2015, Stankowski et al. 2017), serpentine tolerance in Arabidopsis arenosa (Arnold et al. 2016), and winter coat color in various species of hares (Jones et al. 2018, Giska et al. 2019). In many other cases, hybridization is hypothesized to have allowed species to 
expand their ranges, although the genes that are responsible have not always been determined (e.g., Cupressus, Ma et al. 2019; Populus, Suarez-Gonzalez et al. 2017, Chhatre et al. 2018).

Although the specific genes and adaptations involved for Cherleria are unknown, it is potentially important that of the species included in the current study, C. garckeana, C. laricifolia, and C. sedoides are the only ones with substrate polymorphism. Cherleria garckeana is an edaphic generalist and can be found on calcareous, siliceous, and serpentine substrates (Kamari 1997), with serpentine likely ancestral (Moore and Kadereit 2013). Cherleria laricifolia is largely found on siliceous substrates, except for the serpentine endemic subsp. ophiolitica, and is entirely absent from calcareous substrates. Cherleria sedoides is also an edaphic generalist. All of these species show evidence of hybridization, with $C$. sedoides previously shown to have undergone hybridization with a species that is now extinct (Moore et al. 2017). At least $C$. garckeana and $C$. laricifolia appear to have hybridized with species that are restricted to various different substrates and from which this expansion of edaphic niche might have been obtained. In addition, two of the species with the largest ranges, $C$. laricifolia and $C$. sedoides, showed varying levels of hybridization in different populations or parts of their ranges, potentially indicating that the genes acquired via hybridization were more important in some parts of their ranges than in others. The remaining widespread species, $C$. capillacea s.s., was not sampled well enough in this study to be able to determine the extent of hybridization.

\section{Hybridization as evidence for past distribution}

In addition to the evolutionary implications of hybridization or introgression, past hybridization can shed light on the biogeographic history of a group (Klein and Kadereit 2016). In some cases, phylogenetic or phylogeographic reconstruction is congruent with hybridization, and shows that the hybridizing lineages would have been in the same place at the same time (e.g., Zohren et al. 2016, Burbrink and Gehara 2018, Chhatre et al. 2018). However, in other cases, the parents of the hybrid do not have overlapping ranges today (e.g., Wendel 1989, Wendel and Cronn 2003, Pelser et al. 2012, Flowers et al. 2019). For these species, broader ranges in the past or long distance dispersal followed by extinction likely led to hybridization. For example, New World tetraploid Gossypium is an allopolyploid hybrid between a New World diploid and an Old World diploid that apparently dispersed to the New World and went extinct after the hybridization event (Wendel and Cronn 2003).

We find both scenarios in Cherleria. The range of $C$. garckeana currently overlaps or is adjacent to the ranges of most of the species with which it has hybridized. Although the contemporary ranges of $C$. langii and $C$. capillacea s.s. do not overlap, we detected hybridization between these two species. It is possible that past contact between the eastern-most populations of $C$. capillacea s.s. and the western-most populations of $C$. langii occurred. However, matters are different in $C$. laricifolia. Its range does overlap with that of $C$. capillacea, but the other species with which it has apparently hybridized are restricted to the southern Balkan Peninsula where it does not grow today. We therefore hypothesize that $C$. laricifolia once was more widespread and probably originated on the Balkan Peninsula from where it colonized the 
Alps and western Europe. Interestingly, distribution modeling does not give high support for a more widespread southern range of $C$. laricifolia around the Mediterranean. However, it has been shown that selection takes place during migration (Canestrelli et al. 2016), and, thus, the plants that were able to grow along the Mediterranean were likely genetically and ecologically different from the ones that are now growing in the current range of $C$. laricifolia. A past distribution of $C$. laricifolia in southern areas is also supported by the high genetic diversity and lack of distinctiveness of $C$. laricifolia subsp. ophiolitica from the northern Apennines in Italy (Moore et al. 2013).

\section{Conclusions}

It is generally expected that the use of the increasingly large amounts of data available through phylogenomic methods will eventually yield fully resolved, well-supported phylogenetic trees from even the most recalcitrant groups. However, as we show here, although each individual analysis may recover a relatively well-supported set of relationships, conflict between analyses of the same data set often remains. Instead of considering these conflicts to be noise that distract from understanding the evolution of the group, it is possible to gain new insights into the group, beyond what a single species tree would have told us. As shown here, evidence of past hybridization can both provide clues as to how the group was able to colonize new niches and can serve as an indicator of past distribution ranges.

\section{Methods}

\section{Sample Preparation and Sequencing:}

All species of Clade C of Moore and Kadereit (2013; corresponding to Minuartia section Spectabiles (Fenzl) Hayek subsection Laricifoliae (Mattf.) McNeill series Laricifoliae of McNeill, 1962 with the addition of Cherleria sedoides) were sequenced, with the exception of $C$. handelii Mattf., of which no fresh or silica-dried material was available. In addition, C. rupestris ( $M$. labillardierei Briq.), which formed part of a polytomy with Clade A and Clades B + C in Moore and Kadereit's (2013) phylogeny, was included as an outgroup. In total, 286 individuals from 63 populations were sequenced (Fig. 1, Table 1), with five individuals per population, when the populations consisted of at least five individuals. Sampling was concentrated on C. Iaricifolia (130 individuals from 27 populations) and C. langii (80 individuals from 16 populations) with individuals sampled throughout the ranges of these species. Although the remaining species were sampled at a much lower density, an attempt was made to sample from as much as possible of their ranges.

In order to compare the GBS results with the nrDNA results of our previous study (Moore and Kadereit 2013), RAxML v. 8.2.4 (Stamatakis 2014) was used to reconstruct the maximum likelihood tree from ITS and ETS sequence data, using the GTRCAT model of sequence evolution with 500 bootstrap replicates. The pruned alignment from Moore and Kadereit (2013) was used, with the addition of the remaining populations that were not included in that study. PCR and sequencing were performed as described in Moore and Kadereit (2013). One sequence per population sampled in the current study was included, with 
the exception of $C$. wettsteinii, for which we had only a single sequence. GenBank numbers are given in Additional file 3 .

DNA was extracted from silica-dried leaf material using the Qiagen DNeasy Plant Mini Kit (Qiagen GmbH, Hilden, Germany). Approximately $0.015 \mathrm{~g}$ of dried leaf material was ground in a Retsch MM 301 mill (Retsch $\mathrm{GmbH}$, Haan, Germany) and eluted twice in $50 \mu \mathrm{l} A E$ (elution) buffer.

Libraries were prepared for Genotyping by Sequencing (GBS) following the protocol of Elshire et al. (2011), as modified by Dillenberger and Kadereit (2017). Twenty-five different inline barcodes were used

(the numbers $3,5,6,8,9,11,12,14,17,19,25,30,35,36,37,38,39,41,57,60,61,69,78,79$, and 81 from Elshire et al. 2011) and combined with different third-read barcodes (TS01, TS04, TS05, TS06, and TS07) for multiplexing. Primers were obtained from Eurofins Genomics (Ebersberg bei München, Germany) and Sigma-Aldrich (Sigma-Aldrich Chemie $\mathrm{GmbH}$, München, Germany) and all other reagents were obtained from New England Biolabs (New England Biolabs GmbH, Frankfurt am Main, Germany). PCR products were gel-extracted to remove adapters prior to sequencing using the NucleoSpin Gel and PCR Clean-Up kit (Macherey-Nagel GmbH \& Co. KG, Düren, Germany). Pooled sets of 25 samples were sequenced on an Illumina HiSeq 2000 (Illumina, Inc., San Diego, California, USA) at the Institut für Organismische und Molekulare Evolutionsbiologie, Johannes-Gutenberg Universität Mainz, Germany. Each set of 25 samples was sequenced on approximately 0.20 lane. NCBI SRA accession numbers for each individual are given in Additional file 3.

\section{Read Processing and Grouping into Loci:}

Processing of sequence data was carried out using the RTD pipeline (Peterson et al. 2012) as modified using custom python scripts (found at https://github.com/abigail-Moore/GBS-analysis/), as described by Dillenberger and Kadereit (2017). A full description of the individual scripts is found in the ReadMe file in the git repository. Only 25 individuals, representative of the group's phylogenetic diversity, were run through the RTD pipeline. The remaining individuals were added to the dataset by BLASTing (Altschul et al. 1990) them against the set of loci found using the RTD pipeline and our custom scripts. This two-step analysis protocol allowed us to add individuals relatively quickly, without having to reanalyze the whole dataset. It also allowed us to perform the required analyses on a desktop computer with 16 GB of RAM.

Initial alignments of each locus were produced containing all individuals. These alignments were then filtered in various ways to produce working alignments. Extremely variable loci (those with a variability more than three interquartile ranges above mean variability) were removed, as they likely represented multiple locations in the genome. Each working alignment was produced from the full alignments by removing individuals that had fewer than $10 \%$ of the loci and loci that were present in fewer than $70 \%$ of the individuals. There is a tradeoff between sampling breadth (number of taxa) and sampling depth (number of loci), as many loci are only present in certain taxa, due to losses of restriction sites or large indels. Therefore, different working alignments were produced for each subset of taxa, when they were analyzed separately, instead of simply pruning one master working alignment that contained all individuals with sufficient coverage. 
For each subset of taxa, three different working alignments were produced: The Individual data set contained sequences from all individuals that worked well. The Population data set contained sequences from the single best individual from each population. The Taxon data set contained sequences from the best individual from each taxon, with the Albanian population of $C$. capillacea separated as its own taxon. In cases in which the best individual did not have a sequence for a particular locus, while another member of the same population did have a sequence for that locus, this sequence was used instead (see Table 1 for the populations sampled in this dataset).

The working alignments were then reformatted for the different analyses. For SNP-based analyses, if a given site had more than two SNPs, due to higher ploidy, sequencing errors, or other polymorphisms, two were chosen at random. For sequence-based analyses, one sequence per individual per locus was chosen at random, to allow a concatenated alignment to be made. Bootstrap alignments were made by resampling loci, instead of by resampling sites.

All alignments and trees have been deposited on Dryad (Moore et al. 2020, https://doi.org/10.5061/dryad.47d7wm397).

\section{Sequence-based analyses:}

In order to reconstruct the phylogeny while explicitly taking incomplete lineage sorting (ILS) into account, SVDQuartets (Chifman and Kubatko 2014, 2015) was used, as implemented in PAUP* version 4.0a147 (Swofford, continuously updated). Unlike most species-tree reconstruction programs, SVDQuartets models ILS using SNP data instead of requiring well-resolved and completely sampled gene trees. In the analyses, each individual can be a separate tip, or individuals can be grouped by species (or population) to better reconstruct ILS, and species (or population) trees can be reconstructed. Both population (one sequence per terminal) and species (multiple sequences per terminal) trees were reconstructed for the Population dataset, while population and species trees (both with multiple sequences per terminal) were reconstructed for the Individual dataset. For each analysis, a random set of 100,000 quartets was evaluated and 1000 bootstrap replicates were performed.

The SVDQuartets analysis did not provide branch lengths for the terminal branches. In order to get a comparable topology with branch lengths for all branches, RAXML was used with the GTRCAT model of sequence evolution. Branch support was assessed with 500 bootstrap replicates. The SNP model was not used, as the entire sequences were used for phylogenetic reconstruction, instead of using a dataset composed only of SNPs.

SplitsTree version 4.13.1 (built 16 April 2013; Huson and Bryant 2006) was used to construct phylogenetic networks using the Taxon and Population datasets. The NeighborNet algorithm was used, with uncorrected $p$ distances, which were necessary because the large amount of missing data made other distance estimates less reliable. Branch support was assessed with 1000 bootstrap replicates. 


\section{SNP-based analyses:}

Principal components analysis and discriminant analysis of principal components (DAPC) were performed using adegenet (Jombart 2008, Jombart and Ahmed 2011) in R (R Core Team, 2016). For the DAPC, in the initial clustering (find.clusters function), 50 principal components were used and the maximum number of clusters was set to twice the number of populations. The number of clusters was chosen based on the Bayesian Information Criterion (BIC) values, with ten replicate DAPC analyses run for each number of clusters. For the DAPC analysis of the clustered data (dapc function), the analysis was run initially with a large number of principal components, and the optimal number was chosen for the final analysis based on a-score optimization (optim.a.score function). All discriminant functions (the number of clusters minus one) were used in the final analysis. Individuals were considered admixed if their posterior probability of being assigned to any one cluster was less than 0.9 . In addition, the a-scores of each cluster were calculated (a.score function).

For the DAPC analysis of all individuals (the entire Individual dataset), the lowest BIC values were found when the plants were divided into 18 clusters. However, the groupings at that level were too fine to be useful, and the largest drops in BIC values occurred for each increase in the number of clusters from one through seven. For increases between seven and 18 clusters, although the BIC values continued to decrease, the decreases were much smaller. Therefore, analyses were run with the plants divided into between two and seven clusters. The optimal number of principal components was twelve for almost all analyses of the Individual dataset, with 13 being optimal in some replicates.

For the DAPC analysis of $C$. laricifolia alone, the solution with the lowest BIC value was when the plants were divided into four groups. Analyses were run with the plants divided into two, three, and four groups. Using 10 principal components was optimal for most replicates, with nine principal components being optimal for six replicates. However, when only nine principal components were used, many individuals were not accurately classified into any of the clusters, so the results are based on analyses with 10 principal components.

For the DAPC analysis of $C$. langii alone, the solution with the lowest BIC value was when the plants were divided into two groups. Analyses were run with the plants divided into both two and three groups. Eight principal components were optimal in all but one replicate, in which case nine were optimal. The number of principal components used did not change the results.

We used fineRADstructure (Malinsky et al. 2018), which implements fineStructure (Lawson et al. 2012) for RADseq data, as another way of looking at genetic groupings. We had unmapped data, so used the tag haplotype matrix input format. We were not able to correct for linkage disequilibrium using their sampleLD.R script, as it did not accept this input format. Default settings were used for RADpainter, while finestructure was run with 100,000 burnin iterations and 100,000 sample iterations, with sampling every 1,000 iterations for clustering and default settings with 10,000 burnin iterations for tree building. Results 
were visualized using fineRADstructure. $R$ using $\mathrm{R}$. In all cases, all individuals from each group were analyzed.

Hybridization was assessed with the exhaustive D-statistic test using the Ex $D_{\text {FOIL }}$ wrapper scripts (Lambert et al. 2019) for the $D_{\text {FOIL }}$ scripts (Pease and Hahn 2015). Two different trees were used to construct the five-taxon phylogenies: the SVDQuartets Population tree reconstructed with the Individual dataset, and a RAXML tree reconstructed using the Population dataset. The SVDQuartets tree likely represented the best idea of relationships among the populations (with Pyrenees/Massif Central populations sister to the rest of $\mathcal{C}$. laricifolia) and had accurate internal branch lengths. However, its terminal branches were all of equal length. The RAxML tree likely had more inaccurate relationships (e.g., Pyrenees/Massif Central populations were nested within the rest of $C$. laricifolia), but all branch lengths, terminal and internal, were based on the data. Given the fact that the terminal branches were all relatively long and approximately equal in length in the RAXML tree, it seemed that using the SVDQuartets tree, in which at least the internal branches were accurate, was a better idea than reconstructing a RAxML tree with the SVDQuartets tree as the constraint. Trees were made ultrametric using TreePL (Smith and O'Meara 2012). The initial run of ExD $D_{F O I L}$ was conducted using the prime option to find the optimal analysis parameters, which were then used in the final run. Cherleria rupestris was used as the outgroup in both TreePL and ExD $D_{\mathrm{FOIL}}$, and all 205,457 comparisons were tested. Initially, the number of tests that reconstructed introgression between each of the species was used, and species with more than 50 predicted introgression events were examined in detail, to determine the amount of introgression between the various populations.

\section{Species Distribution Modeling:}

Herbarium collections of Cherleria capillacea, $C$. langii, and C. laricifolia from B, BM, BRU, E, F, K, M, MJG, $M S B, N Y, W, W U, Z$, and ZT were georeferenced. These specimens were either obtained on loan $(E, F, M$, $\mathrm{JSB}, \mathrm{W}, \mathrm{WU}, \mathrm{Z}$, and $\mathrm{ZT}$ ) or locality information was recorded during herbarium visits after specimen identity was verified ( $B, B M, B R U, E, K, M J G, N Y, W, W U$ ). All localities visited in the course of our work were also included (vouchers housed in MJG). In a few cases, data were also obtained from the Global Biodiversity Information Facility (GBIF, www.gbif.org/) for the cases when only a single species of Cherleria grew in that area.

All records lacking coordinates were georeferenced using a combination of maps of the areas in question, Google Earth Pro (versions 7.3.2.5776 and earlier, Google LLC, Mountain View, CA), and OpenStreetMap (www.openstreetmap.org). Only records that could be georeferenced to within $1000 \mathrm{~m}$ were used and exact duplicate records were eliminated. In total, we were left with 57 records for $C$. capillacea, 55 records for $C$. langii, and 229 records for $C$. laricifolia. The records from $C$. laricifolia subspp. laricifolia and ophiolitica were combined because subsp. ophiolitica is nested within subsp. laricifolia and because there were too few records of subsp. ophiolitica to analyze alone. Due to a relatively small number of available data points, all available localities were used that could be georeferenced, regardless of year. The ages of the localities ranged from 1836-2012 (C. capillacea), 1844-2011 (C. langii), and 1823- 
2012 (C. laricifolia), although some specimens did not have collection dates and could have been older than these ranges. These records were exclusively from the native range of the plants, as they are not known to be introduced anywhere. All records were within the known ranges of the species.

The analyses were carried out over an area including all countries in which the three species of Cherleria occur plus Bulgaria, the Czech Republic, Germany, Moldova, and the Ukraine, as these adjacent countries also contained potentially suitable mountain habitat. All islands were excluded with the exception of Corsica, Crete, Mallorca, Sardinia, and Sicily. All data layers were clipped to this extent and the grid size was rescaled to $1 \mathrm{~km}$ square ( $X, Y$ cell size of $0.0083333333,0.0083333333)$, to be compatible with the BioClim dataset. Clipping and rescaling was carried out in ArcMap 10.4.1 (ESRI, Redlands, CA).

For modeling the current distribution, the BioClim variables derived from the WorldClim 2 dataset were used (Fick and Hijmans, 2017), together with a Europe-wide dataset of soil pH (Reuter et al. 2008). For past climates, we used the bioclimatic variables from all three models that were available for the Last Glacial Maximum (LGM): CCSM4 (Gent et al. 2011), MIROC-ESM (Watanabe et al. 2011), and MPI-ESM-P (Giorgetta et al. 2018), all calibrated using WorldClim 1.4.

Preliminary analyses for the three different groups were carried out with all of the variables. In addition, an analysis of correlation of the BioClim variables over the study area was carried out in ArcMap. The variables chosen for the final set of analyses were based on two factors: their importance in the preliminary analyses and their lack of correlation with other variables included in the analysis. Only variables with a correlation coefficient of $<0.70$ were retained. Different variables were retained for the different species.

MaxEnt version 3.4.1 (Phillips et al. 2018) was used to create the all species distribution models (SDMs). Variable importance was measured by jackknifing. The models were run with 10,000 background points, 15 replicates, and 5000 iterations. The replicated run type was subsampled, due to low numbers of points for two of the three species, and all samples were added to the background. The models were developed with $80 \%$ of the data and tested with the remaining $20 \%$. Models were evaluated using the area under the receiver operator characteristic (ROC) curve (AUC values). Separate runs were conducted for each of the three species with each of the three LGM models and both with and without $\mathrm{pH}$ data, for a total of two different reconstructions for current range and six different reconstructions of LGM range per species.

\section{Abbreviations}

AUC

area under the receiver operator characteristic curve cPDNA chloroplast DNA

EAS

European Alpine System

GBS 
genotyping by sequencing

ILS

incomplete lineage sorting

LGM

last glacial maximum

nrDNA

nuclear ribosomal DNA

SNP

single nucleotide polymorphism

\section{Declarations}

\section{Ethics approval and consent to participate}

Not applicable

\section{Consent for publication}

Not applicable

\section{Availability of data and materials:}

All nrDNA sequence datasets are available in GenBank (https://www.ncbi.nlm.nih.gov/genbank/); see Additional File 3 for GenBank accession numbers for each sequence.

Raw GBS data are available in the NCBI Sequence Read Archive (PRJNA613049, https://www.ncbi.nlm.nih.gov/sra/PRJNA613049); see Additional File 3 for NCBI SRA accession numbers for each individual.

Scripts used to analyze GBS data are deposited on GitHub (https://github.com/abigail-Moore/GBSanalysis/).

All additional data files, including sequence alignments, tree files, and R scripts are deposited on Dryad (http://dx.doi.org/10.5061/dryad.47d7wm397, Moore et al. 2020).

\section{Competing interests:}

The authors declare that they have no competing interests. 


\section{Funding:}

Funding was provided by the Deutsche Forschungsgemeinschaft (DFG), grant KA 635/17 - 1 to JWK. The funding body had no role in designing the study; in collection, analysis, and interpretation of data; or in writing the manuscript.

\section{Authors' contributions:}

AJM and JWK designed the study. AJM collected the samples and performed labwork. AJM and JEM analyzed the data. AJM and JWK drafted the manuscript with contributions from JEM. All authors read and approved the final version of the manuscript.

\section{Acknowledgements:}

The authors thank D. Anastopoulos, M. Aoki, C. Bohne, M. S. Dillenberger, S. Gencheva, J. Ichter, J. Klein, J. E. Moore, W. L. Moore, K. Rajcová, J. Smatanová, P. Trigas, and R. L. Welch for assistance in the field; V. Papasotiropoulos, G. Tohmé, and P. Trigas for plant material; M. S. Dillenberger, D. Merges, and S. Wienken for assistance in the laboratory; the national and local authorities in the countries in which we collected including the Parc National du Mercantour, France (J. Ichter, M.-F. Leccia; Décision 2011 - 173), the Parco Naturale Alpi Marittime, Italy (M. De Biaggi, P. Fantini, L. Giraudo; Protocollo 3302), and the Parco Naturale Regionale dell'Aveto, Italy (A. Campomenosi; Protocollo 488) for permission to collect; and the Conservatoire Botanique National Alpin, the Base de données SILENE du Conservatoire Botanique National Méditerranéen /SILENE database of the Conservatoire Botanique National Méditerranéen, Z. Barina, P.-E. Biron, W. Guttermann, L. Melovski, and the herbaria B, BM, BRU, E, F, K, M, MJG, MSB, NY, W, $\mathrm{WU}, \mathrm{Z}$, and ZT for locality information.

\section{References}

Abbott R, Albach D, Ansell S, Arntzen JW, Baird SJE, Bierne N, Boughman J, Brelsford A, Buerkle CA, Buggs R. Hybridization and speciation. J Evolution Biol. 2013;26:229-46.

Aeschimann D, Lauber K, Moser DM, Theurillat J-P. Flora Alpina. Bern: Haupt Verlag; 2004.

Allioni C. Flora Pedemontana sive Enumeratio Methodica Stirpium Indigenarum Pedemontii. Tomus 2. Torino: J. M. Briolus; 1785.

Altschul SF, Gish W, Miller W, Myers EW, Lipman DJ. Basic local alignment search tool. J Mol Biol. 1990;215:403-10.

Alvarez N, Thiel-Egenter C, Tribsch A, Holderegger R, Manel S, Schönswetter P, Taberlet P, Brodbeck S, Gaudeul M, Gielly L, et al. History or ecology? Substrate type as a major driver of spatial genetic structure 
in Alpine plants. Ecol Let. 2009;12:632-40.

Anderson E. Introgressive Hybridization. New York: J. Wiley; 1949.

Anderson E, Stebbins GL. Hybridization as an evolutionary stimulus. Evolution. 1954;8:378-88.

Antonelli A, Kissling WD, Flantua SGA, Bermúdez MA, Mulch A, Muellner-Riehl AN, Kreft H, Linder HP, Badgley C, Fjeldså J, et al. Geological and climatic influences on mountain biodiversity. Nat Geosci. 2018;11:718-25.

Arnold BJ, Lahner B, DaCosta JM, Weisman CM, Hollister JD, Salt DE, Bomblies K, Yant L. Borrowed alleles and convergence in serpentine adaptation. Proc Natl Acad Sci U S A 2016;113:8320-5.

Arnold ML. Natural Hybridization and Evolution. New York: Oxford University Press; 1997.

Arnold ML. Divergence with Genetic Exchange. Oxford: Oxford University Press; 2016.

Beckman EJ, Benham PM, Cheviron ZA, Witt CC. Detecting introgression despite phylogenetic uncertainty: the case of the South American siskins. Mol Ecol. 2018;27:4350-67.

Burbrink FT, Gehara M. The biogeography of deep time phylogenetic reticulation. Syst Biol. 2018;67:74355.

Canestrelli D, Porretta D, Lowe WH, Bisconti R, Carere C, Nascetti G. The tangled evolutionary legacies of range expansion and hybridization. Trends Ecol Evol. 2016;31:677-88.

Chhatre VE, Evans LM, DiFazio SP, Keller SR. Adaptive introgression and maintenance of a trispecies hybrid complex in range-edge populations of Populus. Mol Ecol. 2018;27:4820-38.

Chifman J, Kubatko L. Quartet inference from SNP data under the coalescent model. Bioinformatics. 2014;30:3317-24.

Chifman J, Kubatko L. Identifiability of the unrooted species tree topology under the coalescent model with time-reversible substitution processes, site-specific rate variation, and invariable sites. J Theor Biol. 2015;374:35-47.

Christ H. Über die Verbreitung der Pflanzen der alpinen Region der europäischen Alpenkette. Neue Denkschriften der Allgemeinen Schweizerischen Gesellschaft für die Gesammten Naturwissenschaften. 1867;22:1-85.

Comes HP, Kadereit JW. The effect of Quaternary climatic changes on plant distribution and evolution. Trends Plant Sci. 1998;3:432-8.

Dillenberger MS, Kadereit, JW. Maximum polyphyly: Multiple origins and delimitation with plesiomorphic characters require a new circumscription of Minuartia (Caryophyllaceae). Taxon. 2014;63:64-88. 
Dillenberger MS, Kadereit JW. Simultaneous speciation in the European high mountain flowering plant genus Facchinia (Minuartia s.l., Caryophyllaceae) revealed by genotyping-by-sequencing. Mol Phylogenet Evol. 2017;112:23-35.

Edelman NB, Frandsen PB, Miyagi M, Clavijo B, Davey J, Dikow RB, García-Accinelli-G, Van Belleghem SM, Patterson N, Neafsey DE, et al. Genomic architecture and introgression shape a butterfly radiation. Science. 2019;366:594-9.

Elshire RJ, Glaubitz JC, Sun Q, Poland JA, Kawamoto K, Buckler ES, Mitchell SE. A robust, simple genotyping-by-sequencing (GBS) approach for high diversity species. PLoS One. 2011;6:e19379.

Engler A. Versuch einer Entwicklungsgeschichte der Pflanzenwelt. Leipzig: Wilhelm Engelmann; 1879.

Fick SE, Hijmans RJ. Worldclim 2: new 1-km spatial resolution climate surfaces for global land areas. Int J Climatol. 2017;37:4302-15.

Flowers JM, Hazzouri KM, Gros-Balthazard M, Mo Z, Koutroumpa K, Perrakis A, Ferrand S, Khierallah HSM, Fuller DQ, Aberlenc F, et al. Cross-species hybridization and the origin of North African date palms. Proc Natl Acad Sci U S A. 2019;116:1651-8.

Gent PR, Danabasoglu G, Donner LJ, Holland MM, Hunke EC, Jayne SR, Lawrence DM, Neale RB, Rasch PJ, Vertenstein M, et al.. The Community Climate System Model Version 4. J Climate. 2011;24:4973-91.

Giorgetta MA, Jungclaus J, Reick CH, Legutke S, Bader J, Böttinger M, Brovkin V, Crueger T, Esch M, Fieg K, et al. Climate and carbon cycle changes from 1850 to 2100 in MPI-ESM simulations for the Coupled Model Intercomparison Project phase 5. J Adv Model Earth Sy. 2018;5:572-97.

Giska I, Farelo L, Pimenta J, Seixas FA, Ferreira MS, Marques JP, Miranda I, Letty J, Jenny H, Hackländer K, et al. Introgression drives repeated evolution of winter coat color polymorphism in hares. Proc Natl Acad Sci U S A. 2019;116:24150-6.

Grant PR, Grant BR. Hybridization increases population variation during adaptive radiation. Proc Natl Acad Sci U S A. 2019;116:23216-24.

Gross BL, Turner KG, Rieseberg LH. Selective sweeps in the homoploid hybrid species Helianthus deserticola: evolution in concert across populations and across origins. Mol Ecol. 2007;16:5246-58.

Halliday G. Minuartia. In: Tutin TG, Burges NA, Chater AO, Edmondson JR, Heywood VH, Moore DM, Valentine DH, Walters SM, Webb DA, editors. Flora Europaea. Vol. 1: Psilotaceae to Platanaceae. Second Edition. Cambridge: Cambridge University Press; 1993. p. 152-160.

Heiser CB. Introgression re-examined. Bot Rev. 1973;39:347-66. 
Hewitt GM. Genetic consequences of climatic oscillations in the Quaternary. Philos T Roy Soc B. 2004;359:183-95.

Holderegger R, Thiel-Egenter C. 2009. A discussion of different types of glacial refugia used in mountain biogeography and phylogeography. J Biogeogr. 2009;36:476-80.

Huson DH, Bryant D. Application of phylogenetic networks in evolutionary studies. Mol Biol Evol. 2006;23:254-67.

Jombart T. adegenet. a R package for the multivariate analysis of genetic markers. Bioinformatics. 2008;24:1403-5.

Jombart T, Ahmed I. adegenet 1.3-1: new tools for the analysis of genome-wide SNP data. Bioinformatics. 2011;27:3070-1.

Jones MR, Mills LS, Alves PC, Callahan CM, Alves JM, Lafferty DJR, Jiggins FM, Jensen JD, Melo-Ferreira $\mathrm{J}$, Good JM. Adaptive introgression underlies polymorphic seasonal camouflage in snowshoe hares. Science. 2018;360:1355-8.

Kadereit JW. The role of in situ species diversification for the evolution of high vascular plant diversity in the European Alps-A review and interpretation of phylogenetic studies of the endemic flora of the Alps. Perspect Plant Ecol. 2017;26:28-38.

Kamari G. Minuartia. In: Strid A, Tan K, editors. Flora Hellenica, Vol. 1. Königstein: Koeltz Scientific Books; 1997. p. 170-91.

Klein JT, Kadereit JW. Allopatric hybrids as evidence for past range dynamics in Sempervivum (Crassulaceae), a western Eurasian high mountain oreophyte. Alpine Bot. 2016;126:119-33.

Lambert SM, Streicher JW, Fisher-Reid MC, Méndez de la Cruz FR, Martínez-Méndez N, García-Vázquez UO, Montes de Oca AN, Wiens JJ. Inferring introgression using RADseq and $D_{\text {Foll: }}$ Power and pitfalls revealed in a case study of spiny lizards (Sceloporus). Mol Ecol Resour. 2019;19:818-37.

Lawson DJ, Hellenthal G, Myers S, Falush D. Inference of population structure using dense haplotype data. PLoS Genet. 2012;8:e1002453.

Ma Y, Wang J, Hu Q, Li J, Sun Y, Zhang L, Abbott RJ, Liu J, Mao. K Ancient introgression drives adaptation to cooler and drier mountain habitats in a cypress species complex. Nat Commun Biol. 2019;2:213.

Malinksy M, Trucchi E, Lawson DJ, Falush D. RADpainter and fineRADstructure: Population inference from RADseq data. Mol Biol Evol. 2018;35:1284-90.

Mallet J. Hybridization as an invasion of the genome. Trends Ecol Evol. 2005;20:229-37. 
Manton I. Problems of cytology and evolution in the Pteridophyta. Cambridge: Cambridge University Press; 1950.

Marques DA, Meier JI, Seehausen O. A combinatorial view on speciation and adaptive radiation. Trends Ecol Evol. 2019;34:531-44.

McNeill J. Taxonomic studies in the Alsinoideae: I. Generic and infra-generic groups. Notes from the Royal Botanic Garden Edinburgh. 1962;24:79-155.

Médail F, Diadema K. Glacial refugia influence plant diversity patterns in the Mediterranean Basin. J Biogeogr. 2009;36:1333-45.

Moore AJ, Dillenberger MS. A conspectus of the genus Cherleria (Minuartia s.l., Caryophyllaceae). Willdenowia. 2047:5-14.

Moore AJ, Kadereit JW. The evolution of substrate differentiation in Minuartia series Laricifoliae (Caryophyllaceae) in the European Alps: In situ origin or repeated colonization? Am J Bot. 2013;100:2412-25.

Moore AJ, Merges D, Kadereit JW. The origin of the serpentine endemic Minuartia laricifolia subsp. ophiolitica by vicariance and competitive exclusion. Mol Ecol. 2013;22:2218-31.

Moore AJ, Valtueña FJ, Dillenberger MS, Kadereit JW, Preston CD. Intraspecific haplotype diversity in Cherleria sedoides L. (Caryophyllaceae) is best explained by chloroplast capture from an extinct species. Alpine Bot. 2017;127:171-83.

Moore AJ, Messick JA, Kadereit JW (2020) Data from: Range and niche expansion through multiple interspecific hybridization - a Genotyping by Sequencing analysis of Cherleria (Caryophyllaceae). Dryad Digital Repository. http://dx.doi.org/10.5061/dryad.47d7wm397

Ozenda P. La végétation de la chaîne alpine dans l'espace montagnard européen. Paris: Masson; 1985.

Ozenda P. On the genesis of the plant population in the Alps: New or critical aspects. C R Biol. 2009;332:1092-103.

Pardo-Diaz C, Salazar C, Baxter SW, Merot C, Figueiredo-Ready W, Joron M, McMillan WO, Jiggins CD. Adaptive introgression across species boundaries in Heliconius butterflies. PLoS Genet. 2012;8:e1002752.

Pease JB, Hahn MW. Detection and polarization of introgression in a five-taxon phylogeny. Syst Biol. 2015;64:651-62.

Pelser PB, Abbott RJ, Comes HP, Milton JJ, Möller M, Looseley ME, Cron GV, Barcelona JF, Kennedy AH, Watson LE, et al. The genetic ghost of an invasion past: colonization and extinction revealed by historical 
hybridization in Senecio. Mol Ecol. 2012;21:369-87.

Peterson BK, Weber JN, Kay EH, Fisher HS, Hoekstra HE. Double digest RADseq: an inexpensive method for de novo SNP discovery and genotyping in model and non-model species. PLoS One. 2012;7:e37135.

Pfenning KS, Kelly AL, Pierce AA. Hybridization as a facilitator of species range expansion. P Roy Soc B. 2016;283:20161329.

Phillips SJ, Dudík M, Schapire RE Maxent software for modeling species niches and distributions (Version 3.4.1). http://biodiversityinformatics.amnh.org/open_source/maxent/. Accessed **day** **month** 2018.

R Core Team. R: A language and environment for statistical computing. Vienna: R Foundation for Statistical Computing; 2016. https://www.R-project.org/.

Kamari G. Minuartia. In: Strid A, Tan K, editors. Flora Hellenica, Vol. 1. Königstein: Koeltz Scientific Books; 1997. p. 170-91.

Rieseberg LH, Wendel JF. Introgression and its consequences in plants. In: Harrison RG, editor. Hybrid Zones and the Evolutionary Process. New York: Oxford University Press; 1993. p. 70-109.

Rieseberg LH, Raymond O, Rosenthal DM, Lai Z, Livingstone K, Nakazato T, Durphy JL, Schwarzbach AE, Donovan LA, Lexer C. Major ecological transitions in wild sunflowers facilitated by hybridization. Science. 2003;301:1211-16.

Ronikier M. Biogeography of high-mountain plants in the Carpathians: An emerging phylogeographical perspective. Taxon. 2011;60:373-89.

Schneeweiss GM, Schönswetter P. A re-appraisal of nunatak survival in arctic-alpine phylogeography. Mol Ecol. 2011;20:190-2.

Schönswetter P, Stehlik I, Holderegger R, Tribsch A. Molecular evidence for glacial refugia of mountain plants in the European Alps. Mol Ecol. 2005;14:3547-55.

Sklenář P, Hedberg I, Cleef AM. Island biogeography of tropical alpine floras. J Biogeogr. 2014;41:287-97.

Smith SA, O'Meara BC. treePL: divergence time estimation using penalized likelihood for large phylogenies. Bioinformatics. 2012;28:2689-90.

Soltis DE, Gitzendanner MA, Strenge DD, Soltis PS. Chloroplast DNA intraspecific phylogeography of plants from the Pacific Northwest of North America. Plant Syst Evol. 1997;206:353-73.

Soltis DE, Morris AB, McLachlan JS, Manos PS, Soltis PS. Comparative phylogeography of unglaciated eastern North America. Mol Ecol. 2006;15:4261-93. 
Stamatakis A. RAxML version 8: a tool for phylogenetic analysis and post-analysis of large phylogenies. Bioinformatics. 2014;30:1312-3.

Stankowski S, Streisfeld MA. Introgressive hybridization facilitates adaptive divergence in a recent radiation of monkeyflowers. P Roy Soc B. 2015;282:20151666.

Stankowski S, Sobel JM, Streisfeld MA. Geographic cline analysis as a tool for studying genome-wide variation: a case study of pollinator-mediated divergence in a monkeyflower. Mol Ecol. 2017;26:107-22.

Stebbins GL. Variation and Evolution in Plants. London: Oxford University Press; 1950.

Swofford D. PAUP4a157_ubuntu64 http://phylosolutions.com/paup-test/ (continually updated). Accessed 4 Sept 2017.

Suarez-Gonzalez A, Hefer CA, Lexer C, Douglas CJ, Cronk QCB. Introgression from Populus balsamifera underlies adaptively significant variation and range boundaries in P. trichocarpa. New Phytol. 2017;217:416-27.

Thiel-Egenter C, Alvarez N, Holderegger R, Tribsch A, Englisch T, Wohlgemuth T, Colli L, Gaudeul M, Gielly $\mathrm{L}$, Jogan $\mathrm{N}$, et al. Break zones in the distribution of alleles and species in alpine plants. J Biogeogr. 2011;38:772-82.

Valtueña FJ, Dillenberger MS, Kadereit JW, Moore AJ, Preston CD. What is the origin of the Scottish populations of the European endemic Cherleria sedoides (Caryophyllaceae)? New Journal of Botany. 2015;5:13-25.

Watanabe S, Hajima T, Sudo K, Nagashima T, Takemura T, Okajima H, Nozawa T, Kawase H, Abe M, Yokohata T, et al. 2011. MIROC-ESM 2010: model description and basic results of CMIP5-20c3m experiments. Geosci Model Dev. 2011;4:845-72.

Wendel JF. New World tetraploid cottons contain Old World cytoplasm. Proc Natl Acad Sci U S A. 1989;86:4132-6.

Wendel JF, Cronn RC. 2003. Polyploidy and the evolutionary history of cotton. Adv Agron. 2003;78:13986.

Westergaard KB, Alsos IG, Popp M, Engelskjøn T, Flatberg KI, Brochmann C. Glacial survival may matter after all: nunatak signatures in the rare European populations of two west-arctic species. Mol Ecol. 2011;20:376-93.

Whitney KD, Ahern JR, Campbell LG, Albert LP, King MS. Patterns of hybridization in plants. Perspect Plant Ecol. 2010;12:175-82. 
Whitney KD, Broman KW, Kane NC, Hovick SM, Randell RA, Rieseberg LH. Quantitative trait locus mapping identifies candidate alleles involved in adaptive introgression and range expansion in a wild sunflower.

Mol Ecol. 2015;24:2194-211.

Zohren J, Wang N, Kardailsky I, Borrell JS, Joecker A, Nichols RA, Buggs RJA. Unidirectional diploidtetraploid introgression among British birch trees with shifting ranges shown by restriction siteassociated markers. Mol Ecol. 2016;25:2413-26.

\section{Figures}

Fig. 1

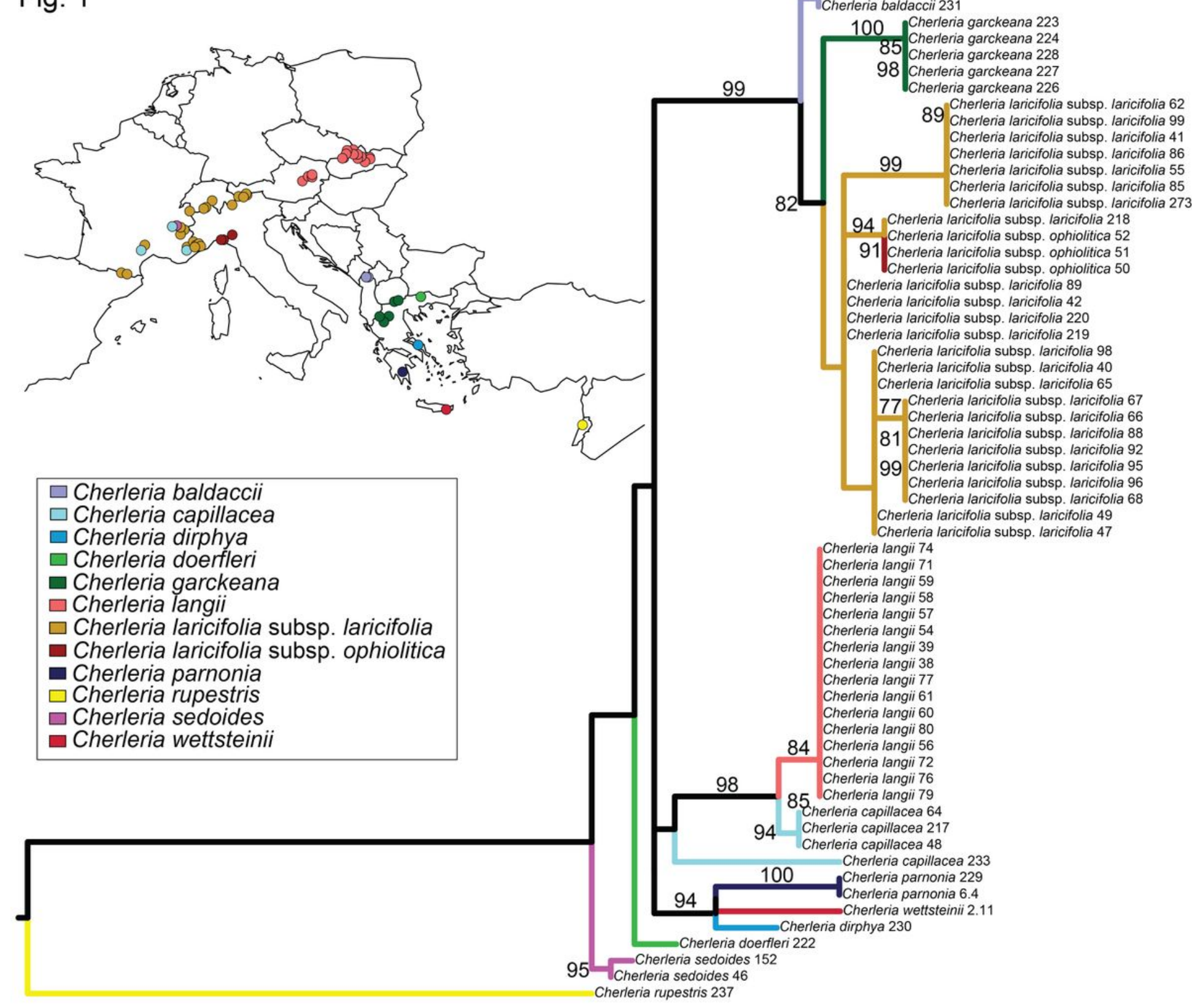

92 Cherleria baldaccii 232

Figure 1 
Phylogeny from the nuclear ribosomal DNA data set and map showing the sampling. Maximum likelihood phylogeny from RAxML, using nuclear ribosomal Internal Transcribed Spacer and External Transcribed Spacer data from the populations sampled in this study. Bootstrap values from 500 bootstrap replicates are above the branches; only values above $70 \%$ are shown. Inset shows the distribution of the sampled populations of each species. The colors of the points and the branches represent the different taxa.

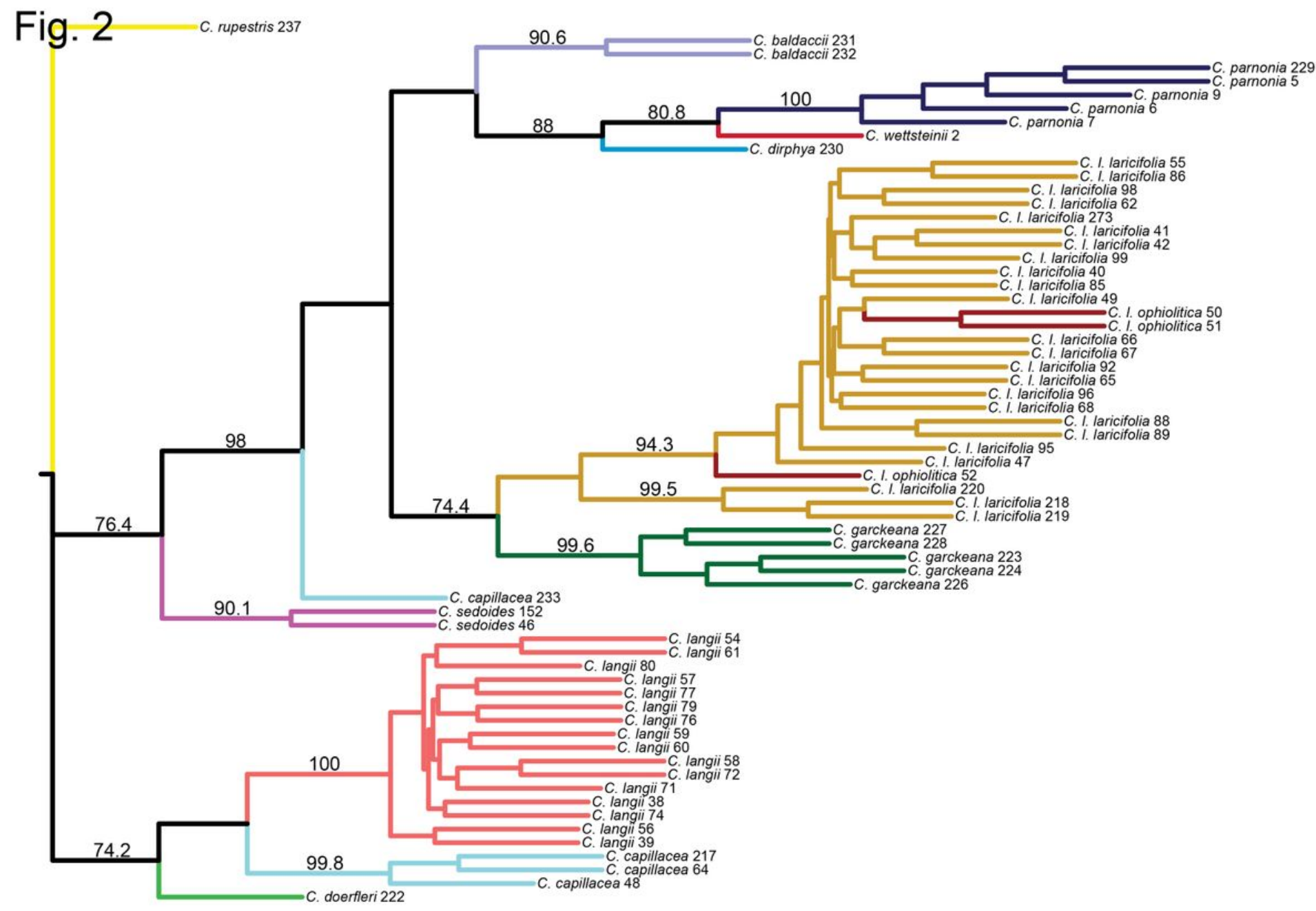

\section{Figure 2}

Population tree from SVDQuartets analysis of the Individual dataset. Bootstrap values from 1000 bootstrap replicates are above the branches; only values above $70 \%$ are shown. 

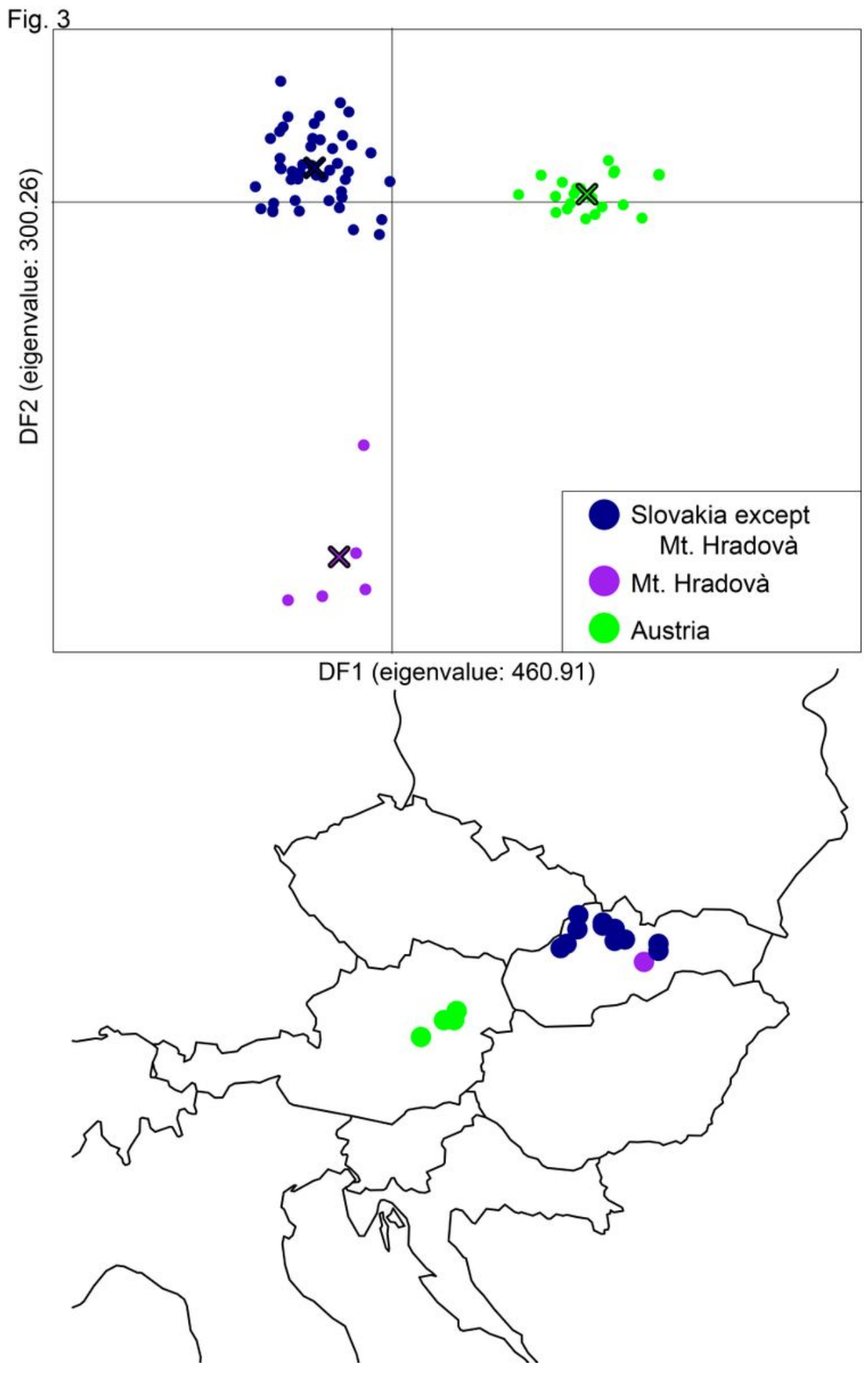

Figure 3

Representative plot from the adegenet analysis of Cherleria langii alone. The plants were divided into three groups, with the distribution of the three groups shown below the plot. 
Fig. 4

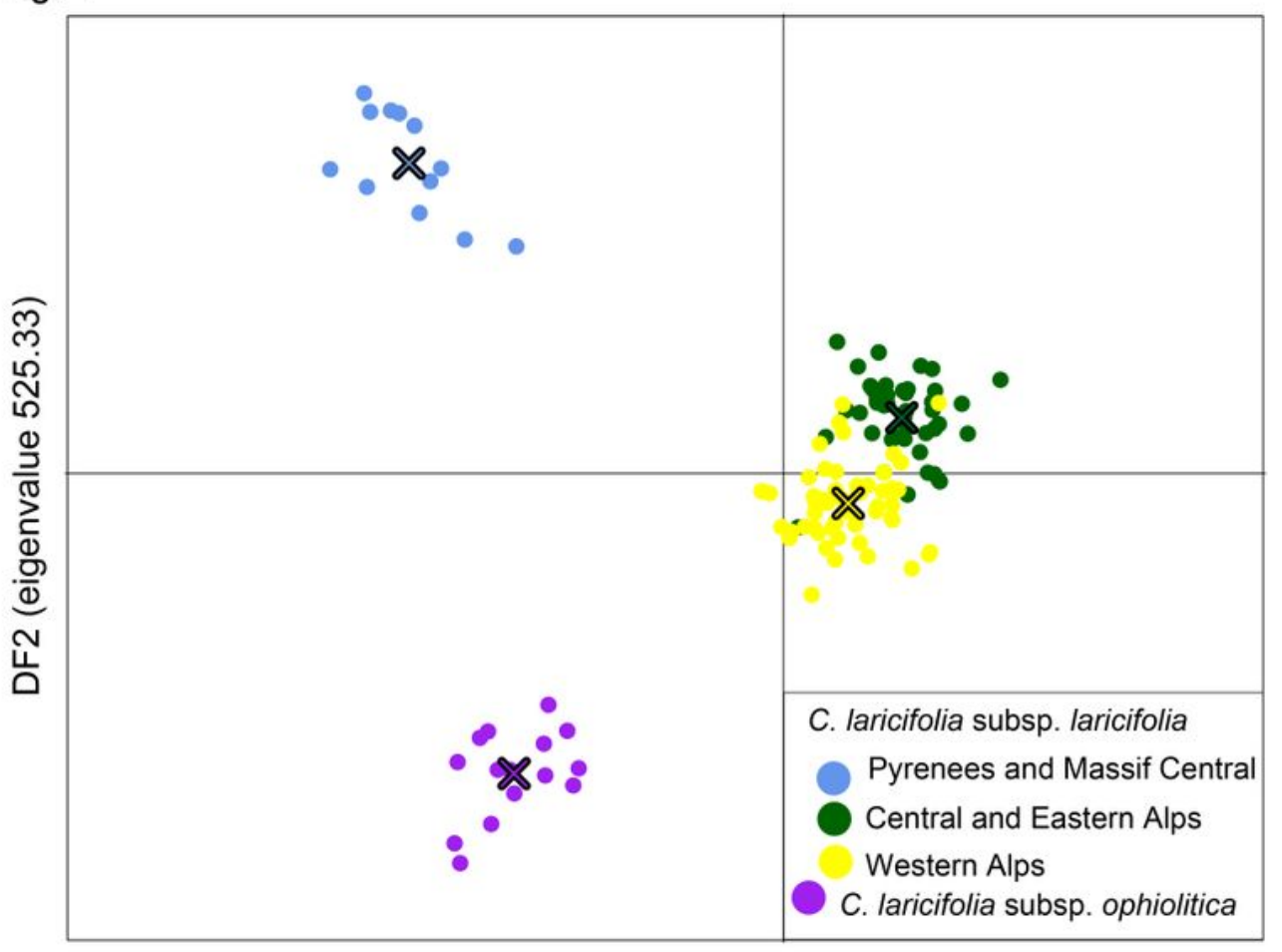

DF1 (eigenvalue 704.78)

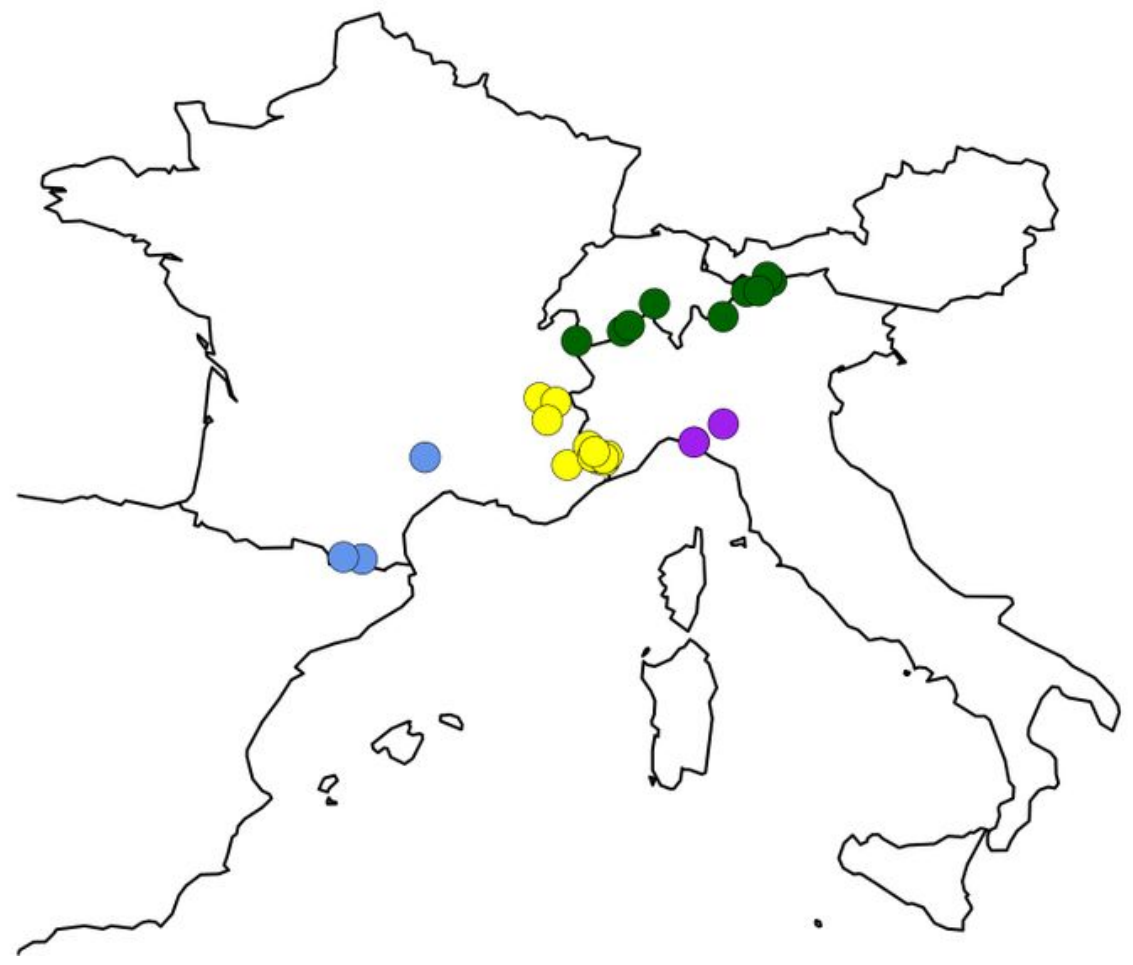

\section{Figure 4}

Representative plot from the adegenet analysis of Cherleria laricifolia alone. The plants were divided into four groups, with the distribution of the four groups shown below the plot. 
Fig. 5

\begin{tabular}{|ll|}
\hline$\square$ Cherleria baldaccii & $\square$ Cherleria laricifolia subsp. laricifolia \\
$\square$ Cherleria capillacea & $\square$ Cherleria laricifolia subsp. ophiolitica \\
$\square$ Cherleria dirphya & 日Cherleria parnonia \\
$\square$ Cherleria doerfleri & $\square$ Cherleria rupestris \\
$\square$ Cherleria garckeana & $\square$ Cherleria sedoides \\
$\square$ Cherleria langii & $\square$ Cherleria wettsteinii \\
\hline
\end{tabular}

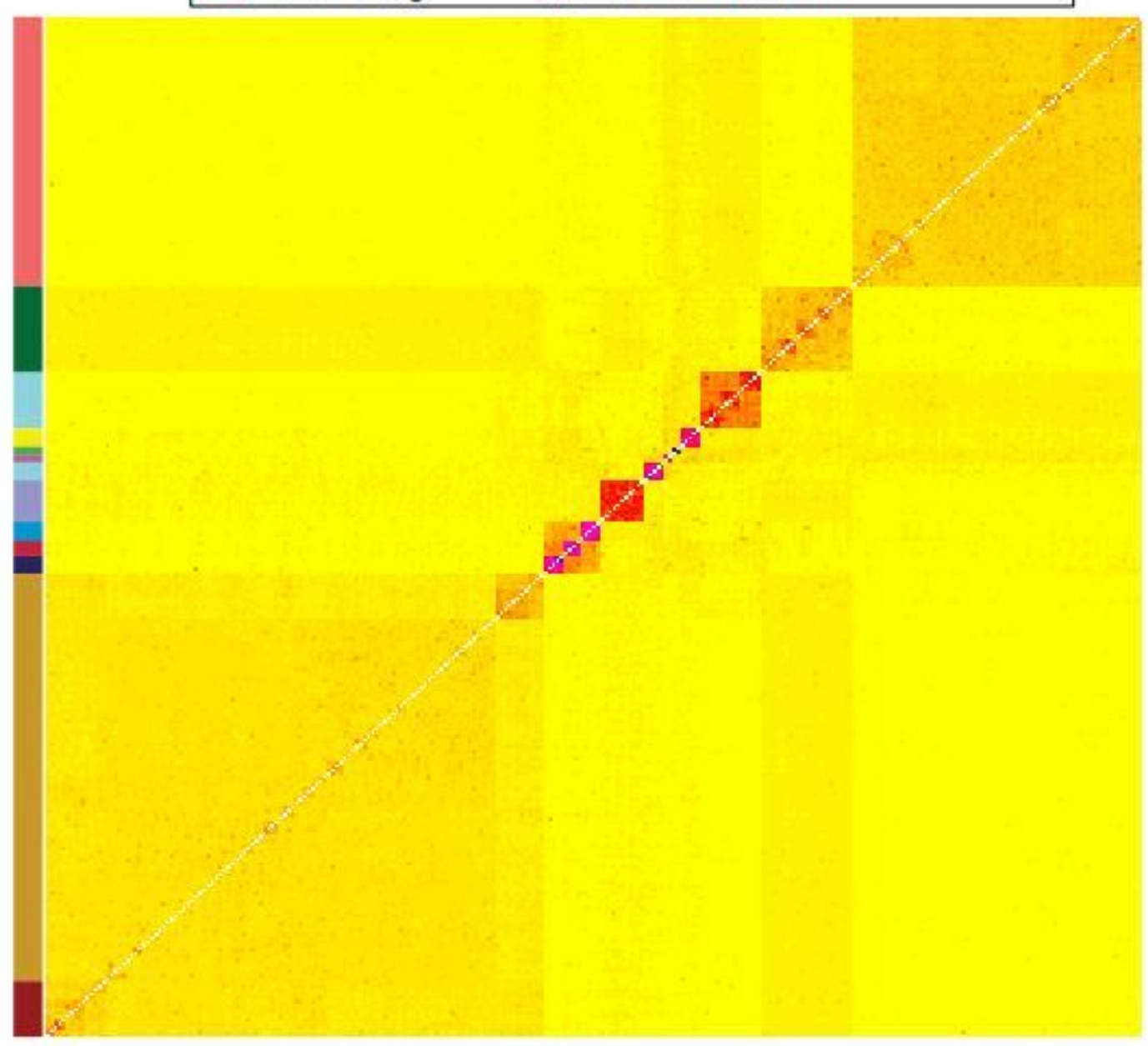

\section{Figure 5}

Plot from the fineRADstructure analysis of all individuals. The color bar on the left side of the figure represents the different species. The colors correspond to those in Figure 1. 
Fig. 6a: Cherleria capillacea

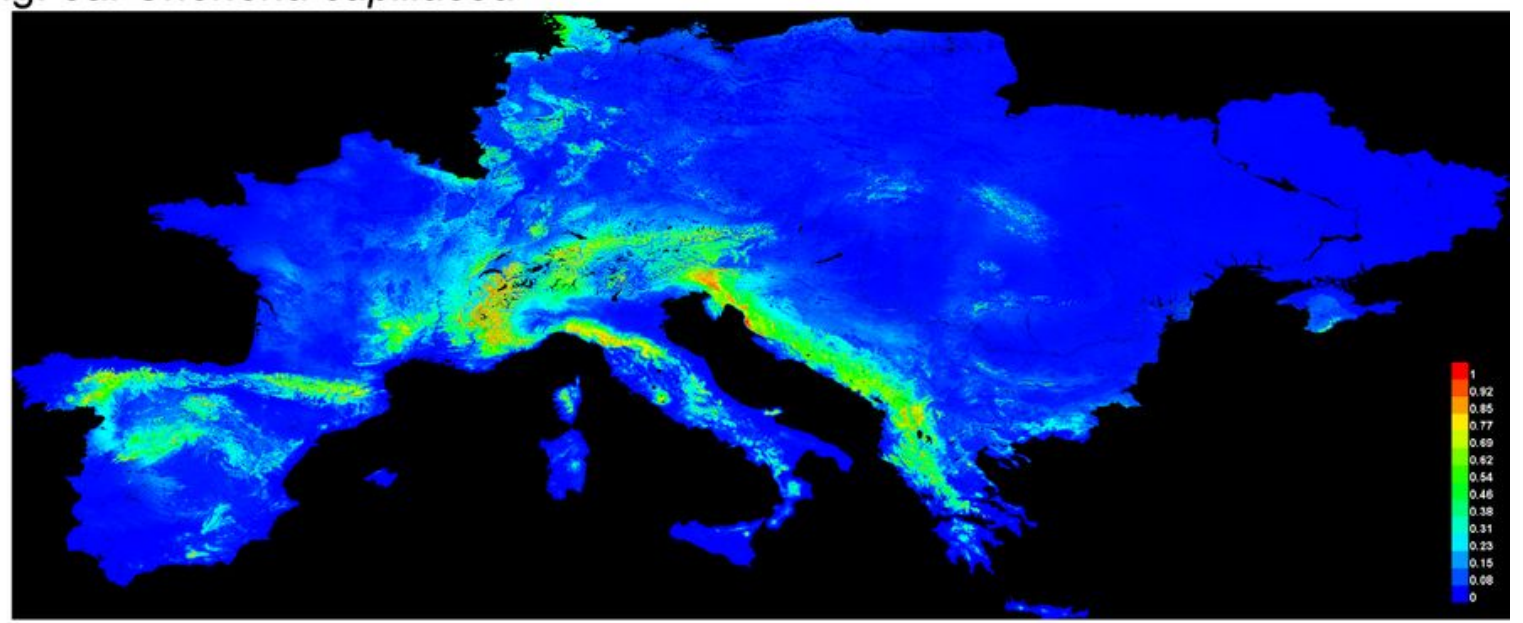

Fig. 6b: Cherleria langii

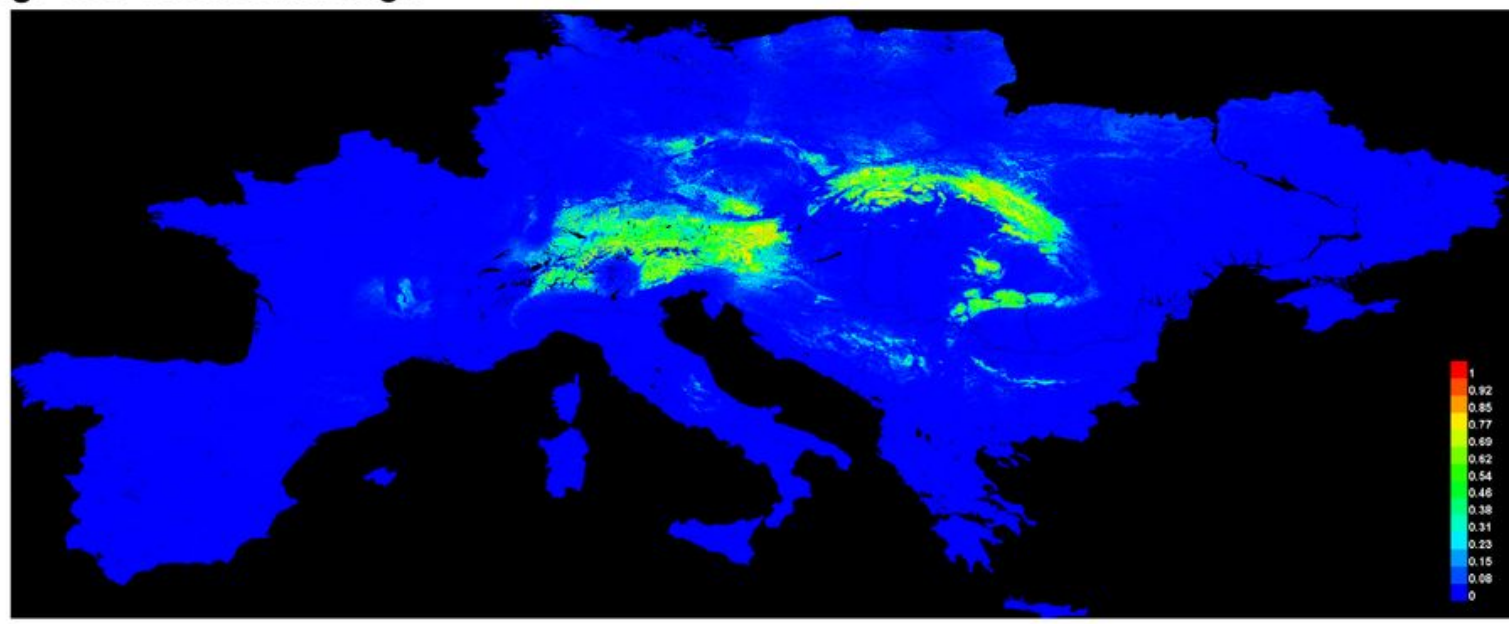

Fig. 6c: Cherleria laricifolia

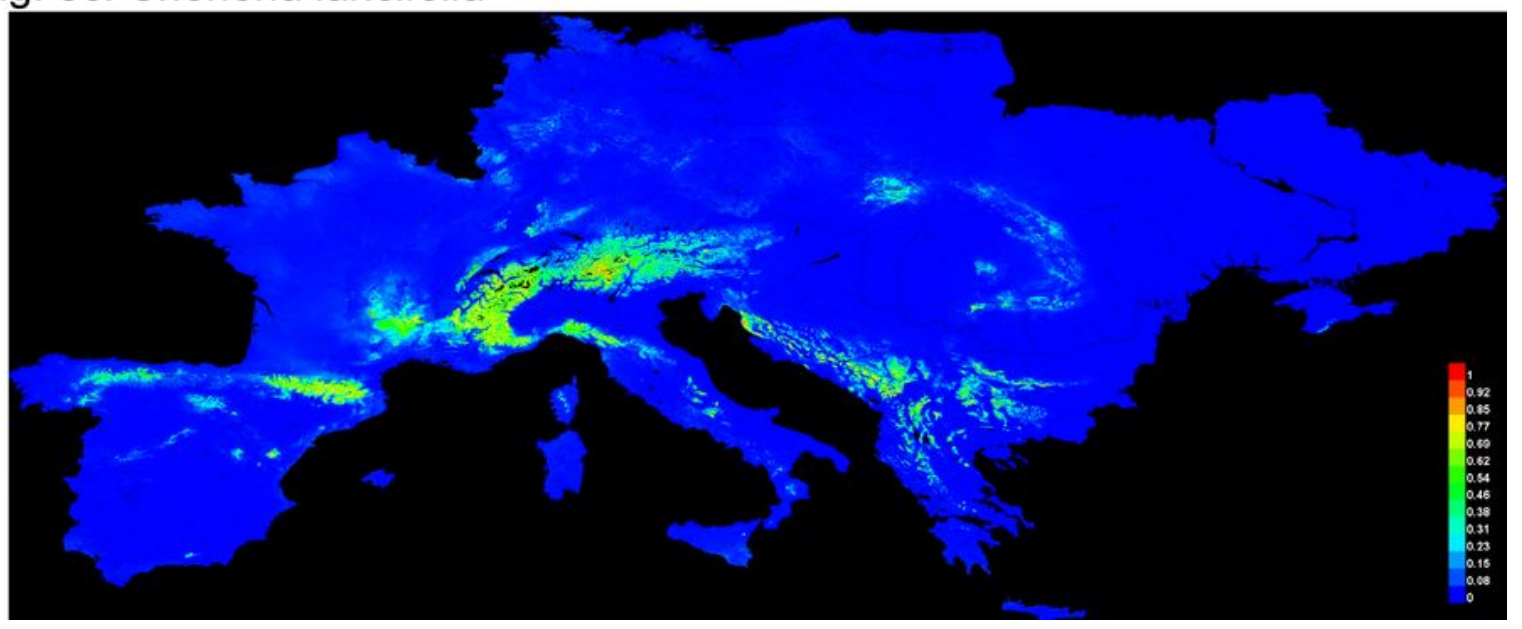

Figure 6

Modeled species distributions for Cherleria capillacea, C. langii, and C. laricifolia. Models were from MaxEnt based on BioClim variables and $\mathrm{pH}$. Maps show the model of the current distribution with the occurrence records used to create the model for C. capillacea (6A), C. langii (6B), and C. Iaricifolia (6C).

\section{Supplementary Files}


This is a list of supplementary files associated with this preprint. Click to download.

- SupplFigures20200319SDMs.pdf

- AdditionalFile1 reads.txt

- AdditionalFile3GBSRA.txt

- AdditionalFile2hybridization.txt

- SupplFigures20200319.pdf 